\begin{tabular}{|c|c|c|c|}
\hline Article Info & \multicolumn{2}{|c|}{\begin{tabular}{l|l} 
RESEARCH ARTICLE & ARAŞTIRMA MAKALESİ
\end{tabular}} & \\
\hline Title of Article & \multicolumn{2}{|c|}{$\begin{array}{c}\text { The Role of Women in Space and Its Effect } \\
\text { on Vernacular Housing Architecture }\end{array}$} & \\
\hline $\begin{array}{l}\text { Corresponding } \\
\text { Author }\end{array}$ & \multicolumn{2}{|c|}{$\begin{array}{l}\text { F.Demet AYKAL } \\
\text { Dicle Üniversitesi Mimarlık Fakültesi, Mimarlık Bölümü, demetaykal@gmail.com }\end{array}$} & \\
\hline $\begin{array}{l}\text { Received Date } \\
\text { Accepted Date }\end{array}$ & \multicolumn{2}{|c|}{$\begin{array}{l}06.04 .2021 \\
12.06 .2021\end{array}$} & \\
\hline DOI Number & \multicolumn{2}{|l|}{ https://doi.org/10.35674/kent.910633 } & \\
\hline Author / Authors & $\begin{array}{l}\text { Eylem AKDEMIR } \\
\text { F. Demet AYKAL }\end{array}$ & $\begin{array}{l}\text { ORCID: 0000-0001-6278-9623 } \\
\text { ORCID: } 0000-0003-2424-0407\end{array}$ & \\
\hline How to Cite & \multicolumn{2}{|c|}{$\begin{array}{l}\text { Akdemir, E. and Aykal, F.D. (2021). Kadının Mekandaki Rolü ve Yöresel Konut } \\
\text { Mimarisine Etkisi, Pages, 482-505 }\end{array}$} & $\begin{array}{l}\text { Kent Akademisi } \\
\text { Urban Acadeny }\end{array}$ \\
\hline
\end{tabular}

\title{
Kadının Mekandaki Rolü ve Yöresel Konut Mimarisine Etkisi
}

Eylem AKDEMIR ${ }^{1}$

Fatma Demet AYKAL ${ }^{2}$

\begin{abstract}
:
Women have impact on life in almost every field from past to present. The woman's point of view, her in-depth examination of the events, and her learning from the events have a great impact on this role. Looking at the ancient ages in the light of scientific studies, it is seen that the woman created the concept of the first cooker and created a space to store food. While the woman was at such an important point, she was later withdrawn from social life due to social, political and religious reasons. Over time, life in traditional area has given individuals different meanings regarding gender in society.

While women are falling behind from their social lives, even public architectural spaces are separated; markets and squares have become men's venues. With the socio-cultural fabric of the society, different freedoms and opportunities have been offered to men and women in different living spaces, and the spaces have been gendered. Therefore, separated spaces belonging to men and women have emerged and separation has been associated with culture. In this context, women's space in traditional houses in different cultural structures and the usage of these spaces by women's is investigated.

In the study, the effect of gender discrimination, which is seen as a problem, in design and spatial setup was examined through traditional houses. From seven regions; seven traditional houses that reflect the climate, social structure and belief of the region where they are located were selected and the spatial organization of the house was evaluated considering the woman. As a result of the evaluations, a regional comparison was made by revealing the effect of women in the houses located in different regions.
\end{abstract}

KEYWORDS: woman, architectural space, traditional housing, privacy 
ÖZ:

Kadın geçmişten günümüze hemen her alanda hayatı etkilemiştir. Kadının bakış açısı, olayları derinlemesine incelemesi, olaylardan ders çıkarmasının bu roldeki etkisi büyüktür. Bilimsel çalışmalar 1şı̆̆ında ilk çağlara bakıldığında kadının, ilk ocak kavramını ortaya çıkardığı ve yiyecekleri saklamak için alan yarattığı görülür. Kadın böyle önemli bir noktadayken daha sonra toplumsal, politik, inanç gibi nedenlerden dolayı toplumsal yaşamdan uzaklaştırılmıştır. Zaman içerisinde geleneksel dokulardaki yaşam, bireylere toplum içinde cinsiyete ilişkin farklı anlamlar yüklemiştir. Kadınlar sosyal hayatlarından geride kalırken kamusal mimari mekanlar bile ayrıştırılmış; pazarlar, meydanlar erkeklere ait mekanlar haline gelmiştir. Toplumun sosyo-kültürel dokusuyla kadın ve erkeğe farklı yaşam alanlarında farklı özgürlükler ve imkanlar sunulmuş, mekânlar cinsiyetlendirilmiştir. Dolayısıyla erkek ve kadın ait ayrı mekânlar ortaya çıkmış, ayrışma kültürle ilişkilendirilmiştir. Bu bağlamda farklı kültür yapılarında geleneksel konutlar içerisindeki kadın mekanı ve kadının mekan kullanımının nasıl olduğu araştırılmıştır. Çalışmada problem olarak görülen cinsiyet ayrımının tasarımda ve mekan kurgusunda etkili olması geleneksel konutlar üzerinden incelenmiştir. Yedi bölgeden; bulunduğu bölgenin iklimini, toplumsal yapısını, inancını yansıtan yedi adet geleneksel konut seçilmiş ve kadına göre konutun mekan organizasyonu değerlendirilmiştir. Değerlendirmeler sonucunda farklı bölgelerde yer alan konutlarda kadının etkisi ortaya konularak, bölgesel bir karşılaştırma yapılmıştır.

ANAHTAR KELIMELER: kadın, mimari mekan, geleneksel konut, mahremiyet

\section{"Kadının Mekandaki Rolü ve Yöresel Konut Mimarisine Etkisi”"}

\section{GİRIŞ:}

Kadınlar geçmişten günümüze evlerinde eş ve anne olarak çeşitli sorumluluklar üstlenmişlerdir. Bazı dönemlerde kadınlar erkeklerle beraber evin yiyecek ihtiyacını karşılarken, bazı dönemlerde ise kadından sadece evin ve çocuklarının bakımını üstlenmesi beklenmiştir. Kadının farklılaşan rolü ile birlikte mimari mekanlar da kadınlara göre biçimlenmiştir.

Geçmişten günümüze kadar kadının mekânı, temel olarak ev olmuştur. Sadece tarihe bakıldığında tanrıçalar için yapılan tapınaklar; rahibelerin kurdukları manastırlar kadın için düşünülen mekanların daha büyük olduğunu göstermektedir. Kente ölçeğinde de kamusal mekanlar kadınların gündüzleri kısmen ve nadir kullandıkları mekânlar olmuştur. Toplumun karar verdiği kadını ve erkeği ayrı tutma anlayışı dini yapılarda, alışveriş mekanlarında, meydanlarda hatta kimi durumlarda ev içinde de mekânsal ayırımlarla mimari tasarımlarda görülmüştür. Kadınları mekanla sınırlama toplum baskısının bir yansımasıdır. Bu oluşumunda inanç etkilidir. Bunun sonucunda kadın mahrem görülmüş; kendi evi içinde misafirleri ağarlayacağı, yemek yapacağı, çocuk büyüteceği içe dönük mekanlar tasarlanmıştır.

Çalışmada geleneksel evler incelenerek mekan organizasyonu ve cepheler üzerinden kadının konutun tasarımına etkisine ait analizler yapılmıştır. İncelenen örnekler Cumhuriyet öncesi dönemde yapılmış olan evler olup kadın erkek ayrımının açık bir şekilde görülebileceği örneklerdir. Çalışmada farklı bölgelerden yöresel evler incelenirken Türkiye'nin farklı iklim bölgelerinde yaşayan insanların toplumsal yaşamlarının yansımasını konutlardan görebilmek mümkündür.

Konut tasarımında geleneklere ve dini inanca bağlı olarak kadınlara özel bölümler tasarlanmış ve mahremiyet adı altında dış dünyayla ilişkileri koparılmaya çalışılmışıtır. Çalışmanın problemi kadınlara ait mimari mekanın sadece konut olarak görülmesi ve konut kurgusunda toplumun inançların, cinsiyet ayrımının ve kadın mahremiyetinin mekanların oluşumunda etkili olmasıdır. Buna bağlı olarak geleneksel konutlar incelenerek cinsiyet ayrımcılığı probleminin mekanlara nasıl yansıdığı araştırılmıştır.

Çalışmanın amacı tarihsel gelişmeler ışı̆̆ında kadının eviyle olan bağını ve toplumsal baskının evin organizasyonuna nasıl etki ettiğini ortaya koymaktır. Kadının konuta etkisi açık bir şekilde gösterilirken bu etkiye neden olan parametreler açıklanmıştır. Kadının konut ile pencere boyutları, mahremiyet amacıyla yapılan yüksek bahçe duvarları, cinsiyete göre mekan dağılımı gibi birçok konuda etkileşimini açıklamak amacıyla Türkiye'de yedi bölgede yedi geleneksel konut plan ve cephe özellikleri incelenerek mimari ögeler üzerinden kadın-konut ilişkisi değerlendirmeleri yapılmıştır. Kadın konut tasarımında önemli bir etkiye sahipken bu konunun üzerinde durulmaması araştırmaya ihtiyaç doğurmaktadır. Cinsiyet üzerinden mekan ayrımını geleneksel konutlar üzerinden ortaya koymak günümüz

The Role of Women in Space and Its Effect on Vernacular Housing Architecture 
konutları ile karşılaştırılması ve yüzyıllar içindeki temel yapı birimi olan konutun değişimi üzerine düşünme ve fikir yürütme açısından önemlidir.

Çalışmanın çıkış noktasını kadının yaşamın her alanında ayrıştırılması ve kadına yakıştırılan tek mekanın ev olması üzerine yapılan toplumsal baskı oluşturmuştur. Çalışmada cinsiyet mimarlığı literatür çalışmalarına yer verilerek, tarih boyunca kadının mimarlıkla, mekanla, konutla kurduğu ilişki ve kadın cinsiyetinin konut tasarımına etkileri bilgi ve belgelerle ortaya konmaya çalışılmıştır. Kadının konut tasarımına etkileri, geleneksel konutlar üzerinden, plan şeması ve cepheleri incelenerek değerlendirmeler yapılarak analiz edilmiştir. Değerlendirmede bölgesel çıkarımlar yapılarak Türkiye'nin her bölgesinde kadının toplumsal yerinin konut organizasyonundaki etkisi ortaya koyulmuştur.

Kadın, mekan ve konut kavramları, Türkiye'de kadının mekandaki rolü, konut yapıları konusunda literatür taraması yapılmıştır. Dönem dönem kadın ve mimarlık ilişkisi irdelenmiş ve konut-kadın hakkında yapılan literatür çalışmaları incelenmiştir. Kadının mahrem görülmesinin nedeni olan inanç üzerinden konut yapıları analiz edilirken inanışları ve yaşam biçimleri göz önünde bulundurularak mahremiyet çıkarımları yapılmıştır. Kadının konut üzerindeki etkisini tanımlayabilmek amacıyla Türkiye'de yedi bölgeden yedi adet geleneksel konut incelenerek mekan organizasyonlarında, yapı cephelerinde kadınlar için gerçekleştirilen özel çabalar irdelenmiştir. Daha sonra örneklere bağlı olarak bölge bölge kadının konut üzerindeki etkisi karşılaştırmalı değerlendirilmiş ve sonuçlara varılmıştır.

\section{Tarihsel Süreç İçinde Kadın-Mimarlık İlişkisi}

İ.Ö. 5000 ile 3000 yılları arası Neolitik Çağ’da insanlar artık üretici olmaya başlamışlardır. Bunun sonucunda meslek grupları ve cinsiyet ayrımı başlamıştır. Erkekler avcılık yaparken kadınlar toprağı işlemeye üretmeye başlamışlardır (Turani, 2000).

1848 yılında, Paleolitik Çăg'da yaşayan Neandertal iskeletlerini inceleyen antropologlar, erkek ve kadın arasında, fiziksel açıdan kayda değer bir fark olmadığını kabul etmişlerdir. Dolayısıyla araştırmacılar tarafından, kadının anatomisinin de en az erkeğinki kadar güçlü bir yapıya sahip olması sonucuna dayanılarak, Neandertallerin günlük yaşantıları hakkında bazı değerlendirmeler yapmıştır. Kadın her zaman mağarada kalıp çocuk bakımı ya da yemek pişirme gibi günlük işlerle uğraşmamış, erkeklerle bizzat ava katılmış, onlar gibi av peşinde koşmuştur. Kadın ve erkek arasında belirli bir iş bölümü yoktur, ama sıkı bir dayanışma vardır. Grup içinde kadının da erkek kadar söz sahibi olduğu ve güçlü bir toplumsal statüsü bulunduğu tahmin edilmektedir. Kadın bu dönemde hiçbir zaman ikinci planda kalmamış, en kaliteli besinlerden eşit ölçüde yararlanmıştır (Özbek, 2001).

Kadının evi dışında erkeklerle aynı işleri üstlenmesine rağmen, mağara içinde mekan ayrımı olmasa da iş bölümü ayrımından söz edilebilmektedir. Depolama alanlarının, ocağın bulunduğu alan kadınlara, misafir ağırlanan alanın ise erkeklere ait olduğu söylenebilmektedir.

İ.Ö. 5500 yıllarında Kalkolitik (Bakır-taş) çağın gelişi ile Neolitik Çağ’da başlayan tarım gelişmiş ve iş gücü gereksinimi kadının ve erkeğin çalışmasını gerektirmiştir. Ürünleri depolamak için tesis gerekliliği ortaya çıkmıştır. Bunları depolayan ve koruyanların yine tarımcı kadınlar olduğu Gılgamış destanında geçen Aşk ve Savaş Tanrıçası İnanna'dan (Akadcada İştar) anlaşılmaktadır (Cıbıroğlu, 2004).

Neolitik Çă̆'da oluşmaya başlayan köy merkezleri üzerinde kadınların etkili olduğu, evlerin temellerinden ve mezar kalıntı bulgularından anlaşılmaktadır. Toprağı işleyen bahçeye bakan kadın, çocukların bakımı ve büyütülmesi için yerleşik bir düzeni, köyleri tasarlamıştır (Mumford, 2007).

Ev artık kadınla özdeşleşmiştir. Kadın ev için hasırdan sepet, çocuğu için oyuncak, yemek için ocak, toprağı işlemek için aletler üretmiştir. Böylece ilk konut örneği kadın tarafından oluşturulmuştur.

Ancak Antik Yunan’da artık yavaş yavaş sembollerin erkek kaynaklı olmaya başladığı görülmüştür. Kadın ve mimarlık ilişkisi ilk çağlardan başlayarak özellikle Neolitik Çağ’da hızla gelişmiş, Kalkolitik Çă̆’da kadın ve erkeğin beraberliğinde iş bölümü ile yapı inşasındaki kadın iktidarı azalmaya başlamış ve Tunç Çağı'nda kadın-yapı ilişkisi gerileme sürecine girmiştir (Dostoğlu Türkün vd., 2005).

Henüz tarım faaliyetlerinin başlamadığı İslam öncesi Türk toplumlarında kadın-erkek arasında aile ilişkileri, mülkiyet hakk1 ve siyasi haklar konusunda eşitlik olduğu belirtilmektedir. Hatta ülke yönetiminde "Hatun", "Hakan" ile birlikte söz hakkına sahip olmuş, ata binmiş, silah kullanmış ve savaşlara katılmıştır (İnan, 1964). 
İslamiyet öncesi, ilk Türklerde, yiyeceğin nasıl üretildiğine bağlı olarak, sabit olmayan yaşam biçimleri gözlenmekteydi. Genellikle, avcılık, hayvancılıkla uğraşan göçebe Türkler çadırlarda yaşamaktaydı. Dairesel planlı bu çadırda, batıda kalan bölüm erkeğe ait olup, burası aynı zamanda misafirlerin de ağırlandığı kısımdı. Doğu taraf ise kadına aitti. Bu kısımda yataklar ve mutfak araçları depolanmaktaydı (Şekil 1),(Küçükerman, 1985).
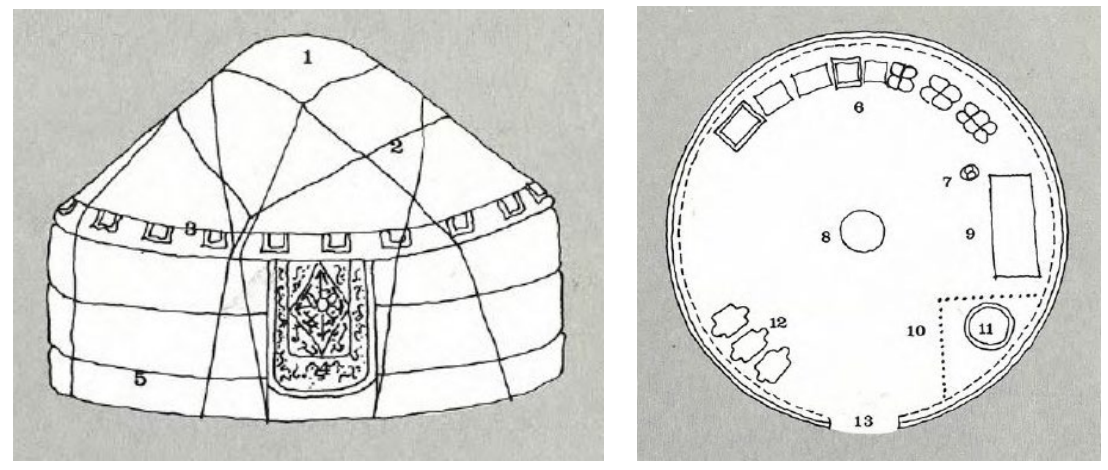

Şekil 1. Dairesel Planlı Türk Çadırı Ön Cephesi ve Planı (Küçükerman, 1985).

Bu bağlamda, çadırdaki mekan düzenlemesi ile geleneksel Türk konutundaki oturma odaları ve özellikle de baş odanın düzenlenmesi arasında bir benzerlik kurulabilir. Ancak İslamiyet sonrasındaki konaklarda görülen harem ve selamlık gibi kadınla erkek arasında mimari bir ayrım söz konusu değildir. Çadır dışında ayrılmayan erkek ve kadın yaşamı, çadır içinde de ayrılmamıştır. Hatta İslam toplumlarında görülenin aksine kadınlar erkeklerle birlikte oturmakta ve konukları ağırlamıştır (Ediz, 1995)

Anadolu sivil mimarisine bakıldığında özellikle konut yapılarında kadınların mekânla olan etkileşimleri gözlenmektedir. Anadolu'da Türkmen konutlarının şekillenmesinde kadınlar aktif rol oynamıştır. Kadınların günlük yaşamdaki eylemleri mimarilerine yansımıştır (Sarıçelik,2017). Böylece mekanlar kadının fikirlerine, yaptığı işlere göre şekillenmiştir. Nesbit'e göre konutlarda fiziksel cinsiyete dayalı ayrım gözeten anlayışın mekânsal örtüşmesi Anadolu evlerinde gözlenen harem-selamlık anlayışıdır. Konut yapısında örtme, direklik, hayat veya dış sofa olarak anılan mekânlar evin kadını ve erkeği tarafindan kullanılan ortak mekanlardır. Buna karşılık başoda, cihannüma olarak adlandırılan mekânlar ise yalnızca evin erkeği ve onun konukları tarafından kullanılan mekanlardır (Nesbit,1992).

Osmanlı Dönemi'nde, toplumsal hayattan soyutlanan kadın, özellikle kentsel alanlarda, konutun içine hatta harem kısmına hapsedilirken, konut dışındaki alanlar, sokaklar erkeklere ait olmuştu. Kadın ve erkeğin dünyaları ayrılmıştı. $\mathrm{Bu}$ durum konut birimleri içinde de aynıdı. Arel, evlerin bu tür mekânsal örgütlenişini doğrudan kültürel verilerle açıklamıştır. Ona göre kültürel yapıya bağlı olarak Osmanlı evi birtakım karşıtlık ilişkileriyle oluşmuştur. Bu karşıtlıklar tipolojik düzeni oluşturmuştur. Ancak bu tipoloji mekan örgütlenişinde karşıt öğelerin birbirinden kopartılarak yalıtılması şeklinde değil, dolaylı olarak, mekânsal nitelik başkalaşmalarıla gerçekleştirilmiştir (Arel,1982). Arel'de, karşıtlıklar ilişkisini dikkate alarak, Osmanlı evinin mekânsal bölünmesini açık-kapalı, içeridışarı karşıtllğ̆ üzerinde ele almıştır (Arel, 1982). Ayrıca odalarin biçimlenmesinde de etkin olan içe dönük bir yaşantı ve ilişkilerdeki kısıtlı çözümlerin ise İslami dünya görüşünden kaynaklandığı vurgulanmaktadır (Tuztaşı, Yüce, 2013)

Özellikle 15 - 18 yy. lar boyunca, mahalle ve konut çevresi, içine kapalı, geleneksel Osmanlı ailesinin bir çeşit doğal uzantısı olmuştur. Mahalle, kadının dış dünyaya açılmasına ve kent yaşamına katılmasına olanak sağlamıştır. Kentsel alandan uzaklaşıp, kırsala doğru gidildiğinde kadının dünyası biraz daha değişmiştir. Din unsuru kırsalda üretken durumda olan kadını kentliye göre daha az etkilemiştir.

Osmanlı Dönemi'nde, Türk kadını kırsal alanda veya kentsel alanda, hatta kentsel alanların farklı bölgelerinde, dinin ya da gündelik hayatın getirdiği bazı yaptırımlar vardı. Bu nedenle kadınlar, farklı yaşam şartları içerisinde olsalar bile, bazen yükümlü oldukları ev işlerinin yoğunluğundan, bazen dokumacılık, yiyecek, giyecek gibi konut için üretimi gerçekleştirdikleri için çoğu zaman da konut dışına çıkma şansları olmadığı için, konutun dominant kullanıcısı olmuşlardır (Yağcı,1998). 
Osmanlı mimarisinde, kadını dış dünyadan izole eden mekânların bulunduğu ve bu mekanların mimariyi şekillendirdiği pek çok örnek vardır. Bunlar iç avlulu evler, büyük kentlerde harem-selamlık ayrımı, mimari ayrıntılar olarak cumba ve pencere kafesleri ile mahallelerde çıkmaz sokak düzenlemeleri örnek verilebilir. Geleneksel İslam kentinin yapısı olarak kent yine erkeğin mekânı, mahalle ve konut ise kadının mekânı olmuştur (Kuban, 2007). Ancak tarih boyunca kadının ve evinin özdeşleştirilmesi, özellikle İslami kurallardan etkilenmiştir..

$\mathrm{Bu}$ örnekler dış cephe ile sınırlı kalmamaktadır. Ataerkil düzene sahip toplumun izleri konut mekanına da yansımış, erkeğin kendisine ait, kadın ve çocuklardan izole olabileceği mekanlar tasarlanmıştır. Kadın gözden sakınılması gereken kişi olduğundan harem ve selamlık sistemi konutlara uygulanmıştır. Selamlık hareme göre konutun merkezinde ve alan olarak daha büyük tasarlanmıştır. Selamlığın çok işlevli ve sade olan haremden daha gösterişli ve düzenli oluşunun erkeğin evdeki konumunu temsil ettiğini belirtmektedir. Harem, oturma odası, yatak odası ve yemek hazırlama mekânından oluşan çok fonksiyonlu bir mekan olmasının yanında kadın mekanı olarak tanımlanmıştır. Büyük konaklarda ya da orta halli aile konutlarında cinsiyet mekân tasarımını şekillendiren bir unsur olmuştur (Şekil 2).
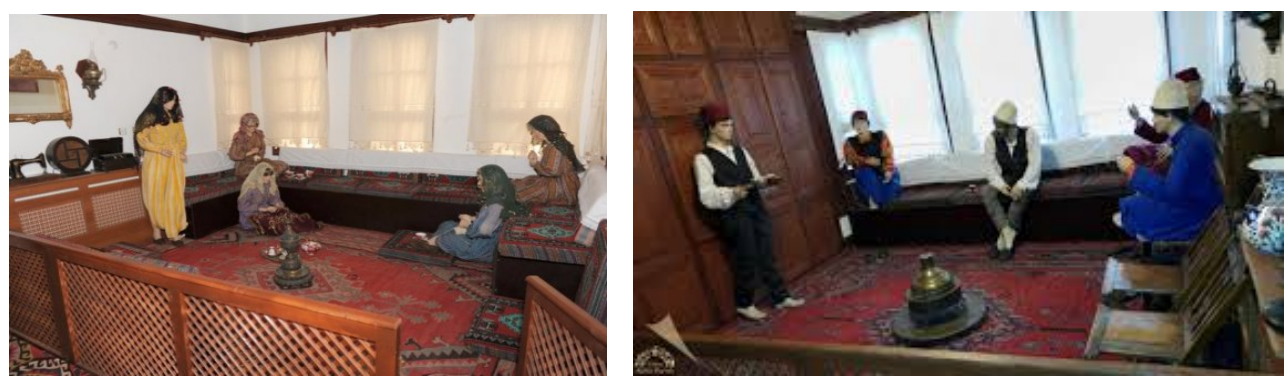

Şekil 2. Harem ve selamlık (URL1-URL2)

\section{Cinsiyet Ayrımının Geleneksel Konut Mimarlığı Üzerinden Analizi}

Çalışmada temel problem olarak cinsiyet ayrımının geleneksel konutlar üzerinden değerlendirilmesi yapılmıştır. Türkiye'de her bölgeden bir geleneksel konut seçilmiş olup plan şemaları incelenmiş ve kadının konuta etkisi üzerinden çıkarımlar yapılmıştır. Her bölgeden bir konut seçilirken o bölgenin mimari özelliklerini yansıtması; seçilen örneklerin Türkiye'de kadın yaşamını değiştiren Cumhuriyet'in ilanından önce yapılmış olmasına dikkat edilmiştir.

$\mathrm{Bu}$ kriterlere bağlı olarak seçilmiş olan yedi konut yapısı aşağıda belirtildiği gibi sıralanmıştır:

- İç Anadolu Bölgesi - Eskişehir Odunpazarı Hasan Şefik Evi

- $\quad$ Ege Bölgesi - Denizli Enver Soylu Evi

- Akdeniz Bölgesi - Antakya Çinçin Ailesi Evi

- Güneydoğu Anadolu Bölgesi - Diyarbakır Mehmet Uzun Evi

- Karadeniz Bölgesi - Rize Fındıklı Aydınoğlu Evi

- Marmara Bölgesi - Bursa Kenan Doğruöz Konağ

- Doğu Anadolu Bölgesi - Erzincan M. Tamer Aksoy Evi

\subsection{Eskişehir Odunpazarı Hasan Şefik Evi}

Yapı Odunpazarı semti, Orta Mahalle, İsa Çelebi Sokak numara 12'de bulunmaktadır (Tablo 1),(Şekil 3-4). 
Tablo 1. Hasan Şefik Evi Künye Bilgileri

\begin{tabular}{|l|l|}
\hline Bulunduğu Bölge & İç Anadolu Bölgesi \\
\hline Konum & Odunpazarı, Eskişehir \\
\hline Yapım Yılı & 19. yy sonları \\
\hline Yapım Sistemi & Ahşap karkas \\
\hline Kat Adedi & Zemin +1 \\
\hline Plan Şeması & İç sofalı \\
\hline
\end{tabular}

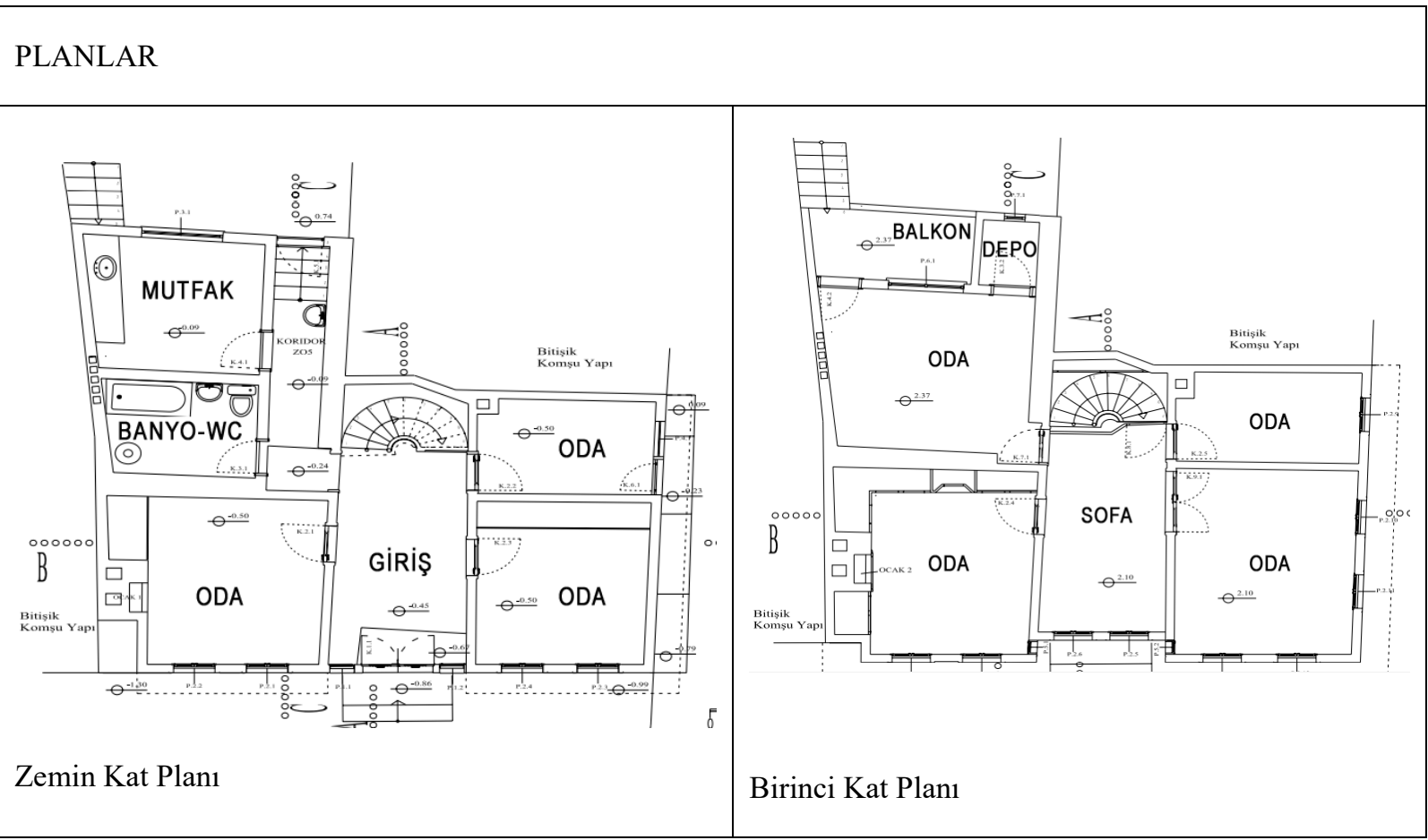

Şekil 3. Hasan Şefik Evi planları (Özer, 2006) 


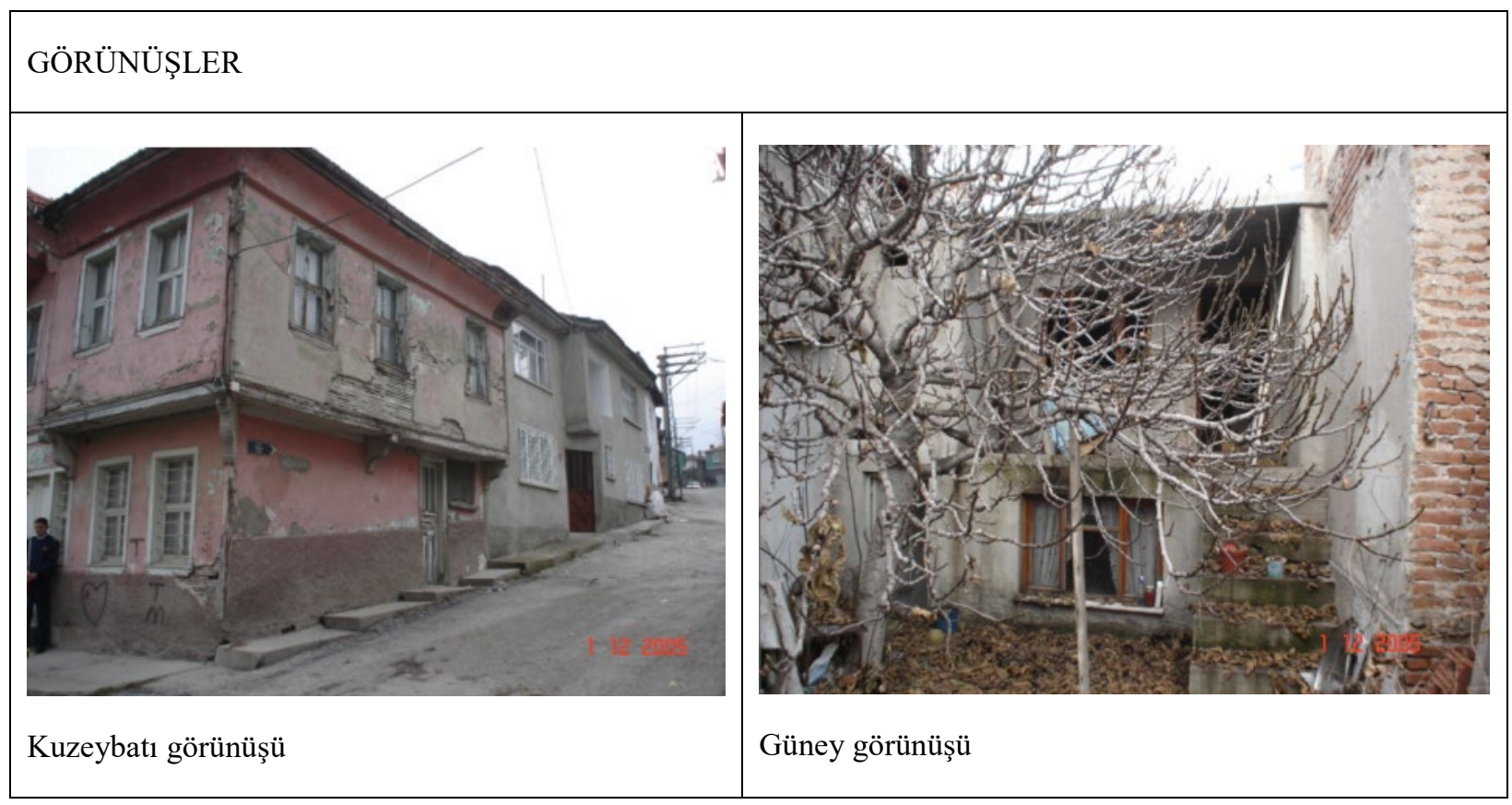

Şekil 4. Hasan Şefik Evi görünüşleri (Özer, 2006)

Yapıya kuzey yönündeki İsa Çelebi Sokak'tan girilmektedir. Yapı bu cephede dıştan dışa $9.90 \mathrm{~m}$ boyutlarında, zemin+1 katlı ahşap karkas bir yapıdır. Yapı iç sofalı geleneksel plan şemasına sahiptir. Giriş kapısına yapının kuzey cephesinden iki basamakla ulaşılmaktadır. Zemin katta giriş mekânı, üç oda, mutfak ve banyo bulunmaktadır (Özer, 2006).

Mutfak ve banyonun bulunduğu koridordan yapının güney cephesinde yer alan bahçeye çıkış vardır. Yapının güneyinde yer alan bahçe içinde, iki bölmeli depo mekânı ile tek bölme helâ yer almaktadır. Yapının giriş mekânında yer alan ahşap merdiven ile tüm oda kapılarının açıldı̆̆ birinci kat sofasına ulaşılmaktadır. Bu katta üç adet oda ile yapıya sonradan eklenen bahçeden merdivenle de ulaşılabilen bir oda, bu oda içinde bir depo bölmesi ve balkonu mevcuttur (Özer, 2006).

-Zemin kat yani genellikle kadınların kullandığı alan daha çok içe kapalıdır, pencere sayısı azdır.

• Birinci kat daha çok dişa dönüktür.

- Başodalar, misafir ağırlanan ve genelde erkeklerin kullandığı oda, daha fazla pencere boşluğu bulunmaktadır.

- Cam açıklıkları her iki katta da aynıdır adet olarak fark etmektedir.

- Yapının zemin kat planına bakıldığında evin hanımının rahatça çalışabilmesi, dinlenebilmesi ve misafirlerini rahatlıkla ağırlayabilecek şekilde mekan organizasyonu yapılmıştır. Arka bahçeyle ilişkili mutfak ve etrafındaki odalar sayesinde kadın bütün işlerini zemin kattan halledebilmektedir.

- Birinci kat planında geleneksel Odunpazarı evleri gibi iki köşede genişçe başodalar bulunmaktadır.

• Odalar Türk evleri gibi, işlevlere ayrılmamış bütün gereksinimler aynı odada gerçekleşmiştir.

- Başoda erkeklere, mutfak ve bahçe kadınlara, diğer odalar ise ailenin bütün kullanıcılarına hitap edecek şekilde inşa edilmiştir. 


\subsection{Denizli Enver Soylu Evi}

Yap1 15 Mayıs Mahallesi, 762. Sokak, No:37 Pamukkale, Denizli’de bulunmaktadır(Tablo 2),(Şekil 5-6).

Tablo 2. Enver Soylu Evi Künye Bilgileri

\begin{tabular}{|l|l|}
\hline Bulunduğu Bölge & Ege Bölgesi \\
\hline Konum & Pamukkale, Denizli \\
\hline Yapım Yılı & 1923 \\
\hline Yapım Sistemi & Ahşap karkas \\
\hline Kat Adedi & Zemin +1 \\
\hline Plan Şeması & Açık(Dış) sofalı \\
\hline
\end{tabular}

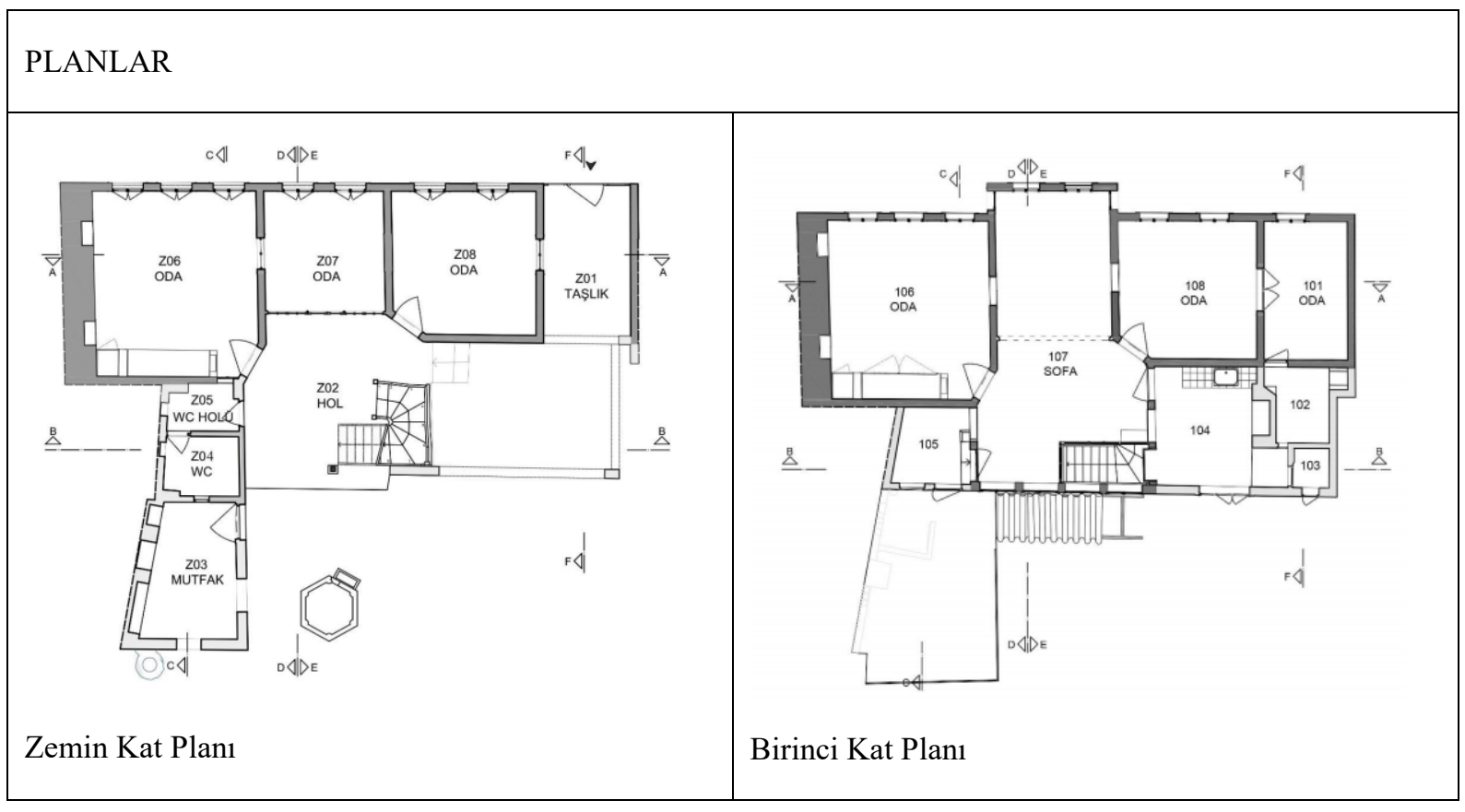

Şekil 5. Enver Soylu Evi Planları (Özderya, 2020) 


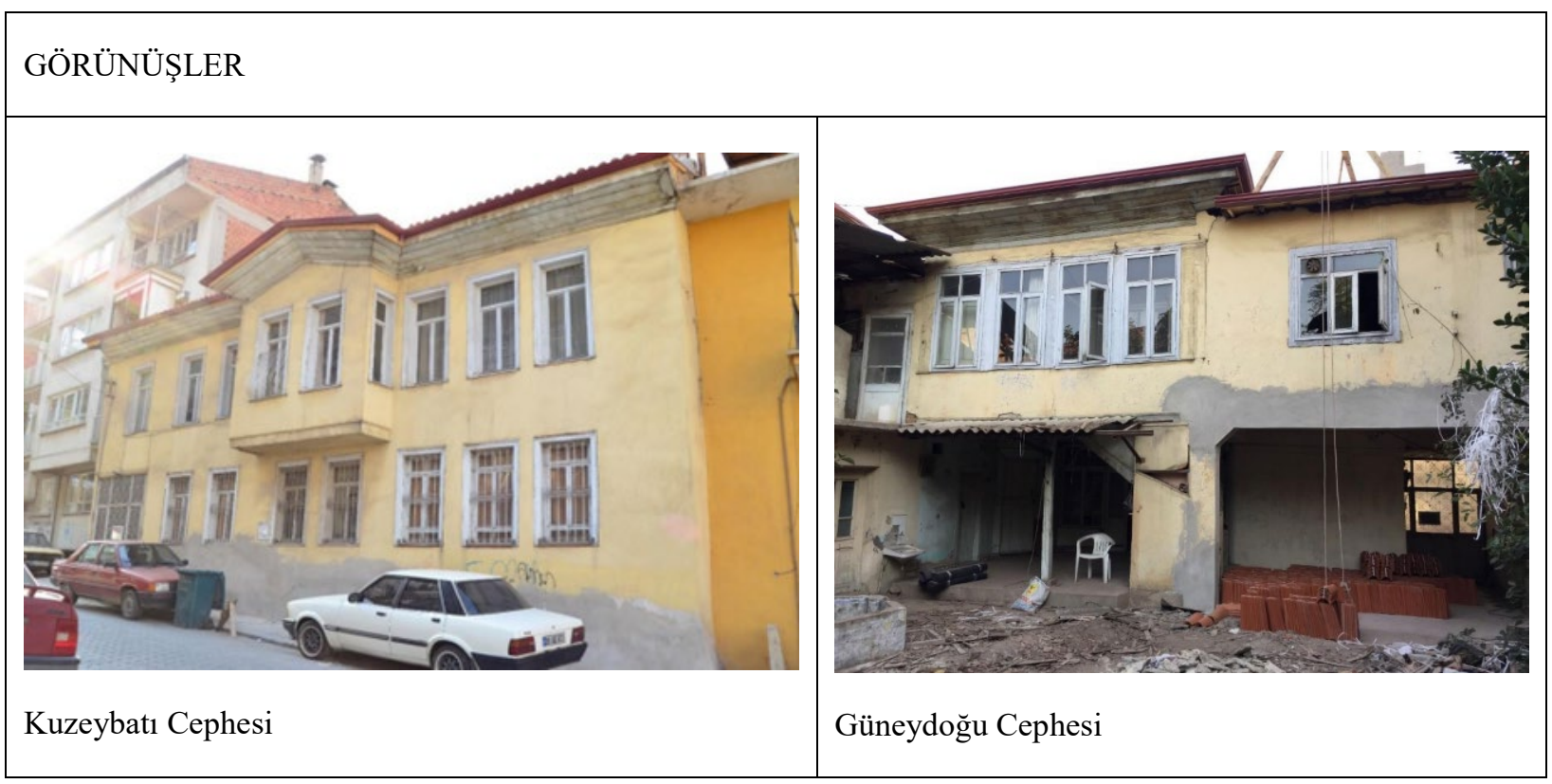

Şekil 6. Enver Soylu Evi Görünüşleri (Özderya, 2020)

1923 yılında yapıldığı bilinmekte olan yapı 2 katlı dikdörtgen plan şemasına sahip kagir bir yapıdır. (Özderya, 2020).

1.katın konsol olarak çalışan bölümleri ahşap dikmeler ile ayakta tutulmaktadır. Yapıya giriş kuzeybatıda 762.Sokak üzerinde bulunan sonradan yapılmış olan demir kapıdan sağlanmakta ve bu kapı doğrudan avluya açılmaktadır (Şekil 9). Avluda zemin kat ile 1.katı bağlayan ahşap döner merdiven vardır. Sofaya açılan odaları ile plan şeması geleneksel Türk Evini yansıtmaktadır. Birinci katta sofanın cephede çıkma yapması ile yola uzanan cumba oluşmaktadır (Özderya, 2020).

- Geleneksel Denizli evlerinde olduğu gibi Enver Soylu Evin'nde de mahremiyet bahçede bulunan büyük ağaçlar ve bahçe duvarlarıyla sağlanmaktadır.

- Pencere sayıları iki katta da aynıdır. Sadece zemin katta güvenlik için pencerelere parmaklıklar koyulmuştur.

- Farklı kullanıcıların iki ayrı katı kullanması mekanları cinsiyete göre ayırmayı zorlaştırmıştır. Mutfak ve tuvalet ortak kullanılmıştır.

- Türk evlerinde sofanın önemi birinci katta sadece çıkma yapılan mekanın sofa oluşundan da anlaşılmaktadır. Sofa tüm ailenin beraber zaman geçirdiği ana mekandır.

- Bu konut örneğinde başoda kavramına rastlanmamıştır. Arka bahçe haricinde mahremiyet önem göstergeleri bulunmamaktadır.

\subsection{Antakya Çinçin Ailesi Evi}

Yapı, Zenginler Mahallesi, Kırk Asırlık Türk Yurdu Caddesi, 3.mıntıka Kastal Sokak'da bulunmaktadır (Tablo 3),(Şekil 7-8). 
Tablo 3. Çinçin Ailesi Evi Künye Bilgileri

\begin{tabular}{|l|l|}
\hline Bulunduğu Bölge & Akdeniz Bölgesi \\
\hline Konum & Antakya, Hatay \\
\hline Yapım Yılı & 19. yy ortaları \\
\hline Yapım Sistemi & Taş kagir \\
\hline Kat Adedi & 1 \\
\hline Plan Şeması & Avlulu \\
\hline
\end{tabular}

\section{PLAN}

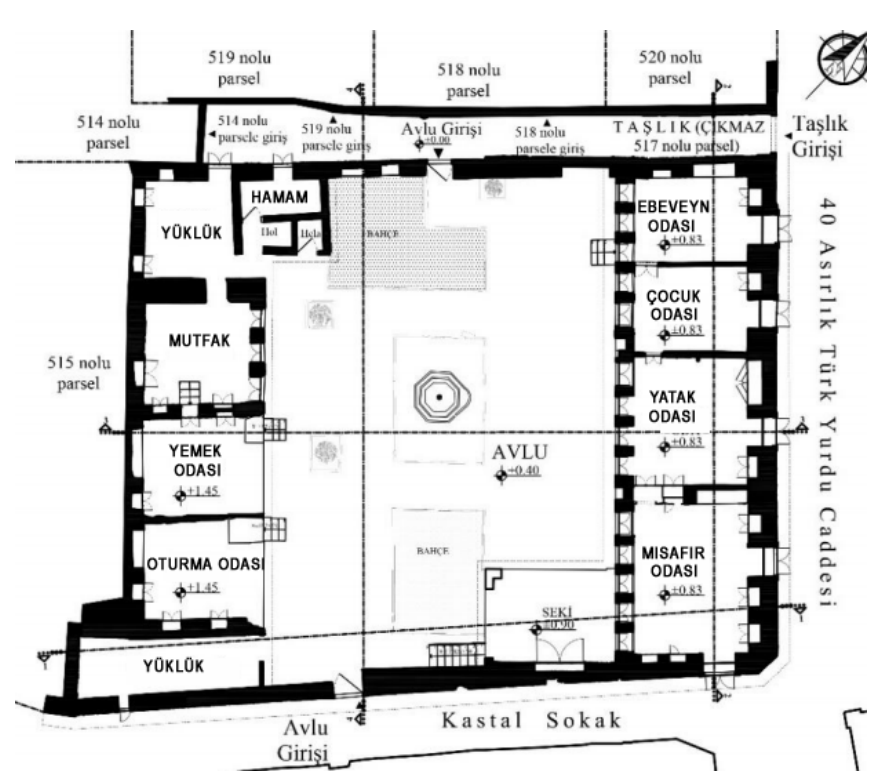

Zemin kat planı

Şekil 7. Çinçin Ailesi Evi Planı (Nurlu, 2020) 


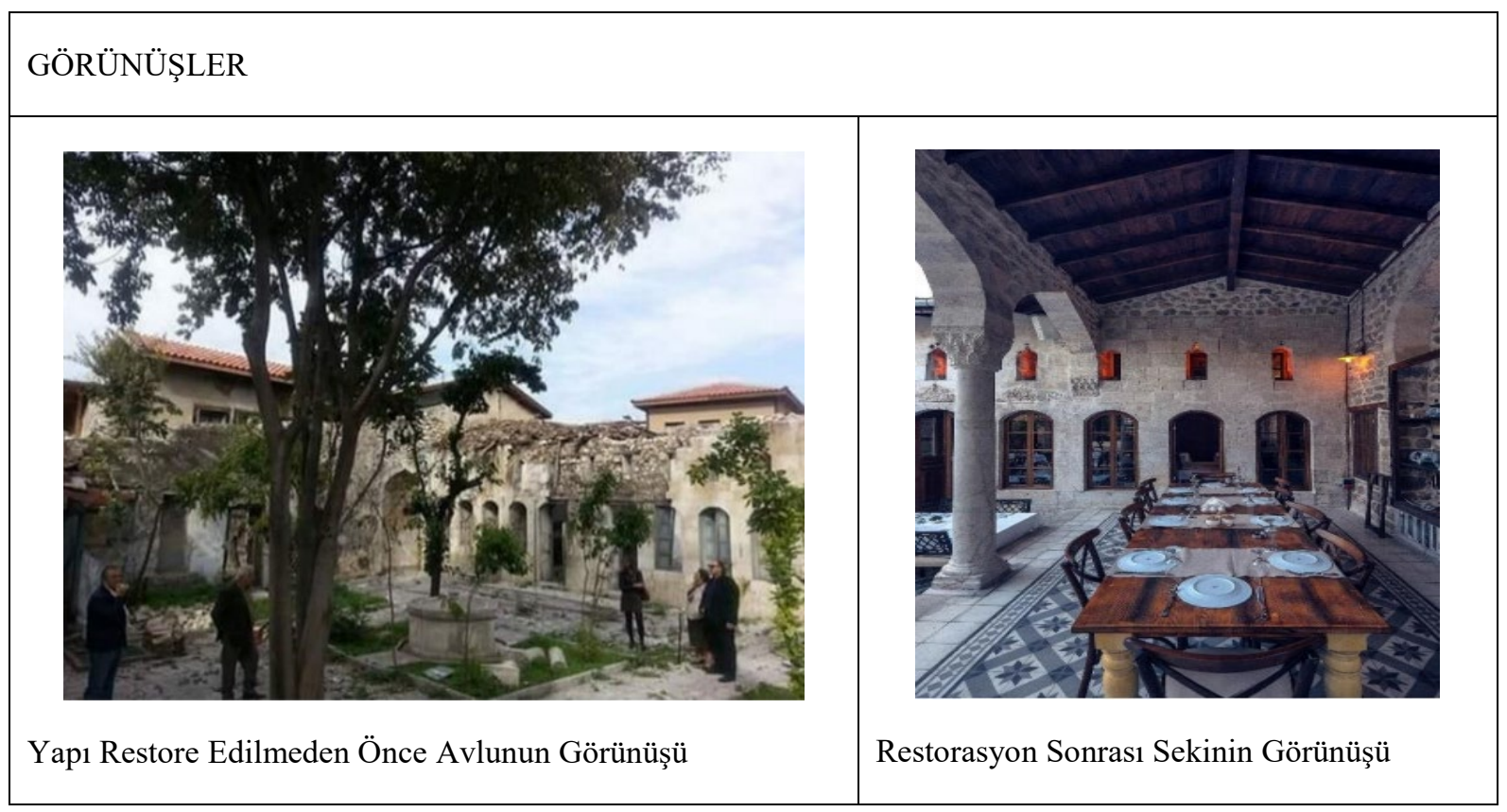

Şekil 8. Çinçin Ailesi Evi Görünüşleri (Nurlu, 2020)

Evdeki biçimsel kullanım incelendiğinde köşede bulunan odada ailenin ebeveynlerinin yaşadığı, çocuk odasında çocukların ve torunların yaşadığı, yatak odasında ebeveynlerin evli olan oğlu Mehmet Çinçin ve eşinin yaşadığı, misafir odasında ise gelen misafirlerin ağırlandığı bilgisi edinilmiştir. Seki hane halkının yaz aylarında vakit geçirdiği bir alan olarak kullanılmaktadır (Nurlu, 2020).

Yüklükler bulgur pirinç gibi baklagillerin saklandığı alanlar olarak kullanılmıştır. Oturma odası ve yemek odası alanları kış aylarında hane halkının bir arada oturduğu ve yemek yediği mekanlardır. Mutfak ve yüklüğün bulunduğu alanın üstünde çatı arası katı bulunmaktadır. Bu alana ulaşım gemici merdiveniyle sağlanıp evin kullanılmayan gereçlerinin saklandığı depo olarak kullanılmıştır. Kış aylarında ssınmak için odun, kömür ya da zeytinin, sıkıldıktan sonra içerisinde bir miktar yağ ve su kalan posası olan prina kullanılmıştır (Nurlu, 2020).

- Antakya tarihi dokusundaki evlerin mimari oluşumunda mahremiyet olgusu büyük önem taşır. Erkekler dışarda çalışırken evin kadınları avluda misafir ağırlar, yemek yer, avluya bakan yüzü açık, dörtgen planlı olan, çoğunlukla üzerleri bir beşik tonoz ile örtülü ve ortalarında küçük bir havuz bulunun livanlarda tahıl kuruturlardı.

- Kadınların zamanının büyük kısmını geçirdikleri avlu yüksek ve kapı dışında açıklığı bulunmayan sağır duvarlarla çevrilidir.

- Bir cephesinde yapı, iki cephesinde avlu duvarları ve bir cephesinde de pencereler açılmış odalar bulunur.

- Odalar işlevlere göre ayrılmıştır.

- Antakya yöresel konutlarında başoda yerine misafir odası bulunmaktadır. Misafir odası Osmanlı'daki selamlık işlevine denk olduğu söylenebilir.

- Çinçin Ailesi Evi'nde yüksek avlu duvarları, penceresiz cepheler, avluya hayat sığdırılması mahremiyetin yaşayan aile için ne kadar önemli olduğu gösterilebilir. 


\subsection{Diyarbakır Mehmet Uzun Evi}

Yapı, Cemal Yılmaz Mahallesi Çizmeci Sokak, 47 pafta, 230 ada, 98 no'lu parselde bulunmaktadır (Tablo 4), (Şekil 9,10).

Tablo 4. Mehmet Uzun Evi Künye Bilgileri

\begin{tabular}{|l|l|}
\hline Bulunduğu Bölge & Güneydoğu Anadolu Bölgesi \\
\hline Konum & Sur, Diyarbakır \\
\hline Yapım Yılı & 19. yy \\
\hline Yapım Sistemi & Taş kagir \\
\hline Kat Adedi & Zemin+1 \\
\hline Plan Şemasi & Avlulu \\
\hline
\end{tabular}

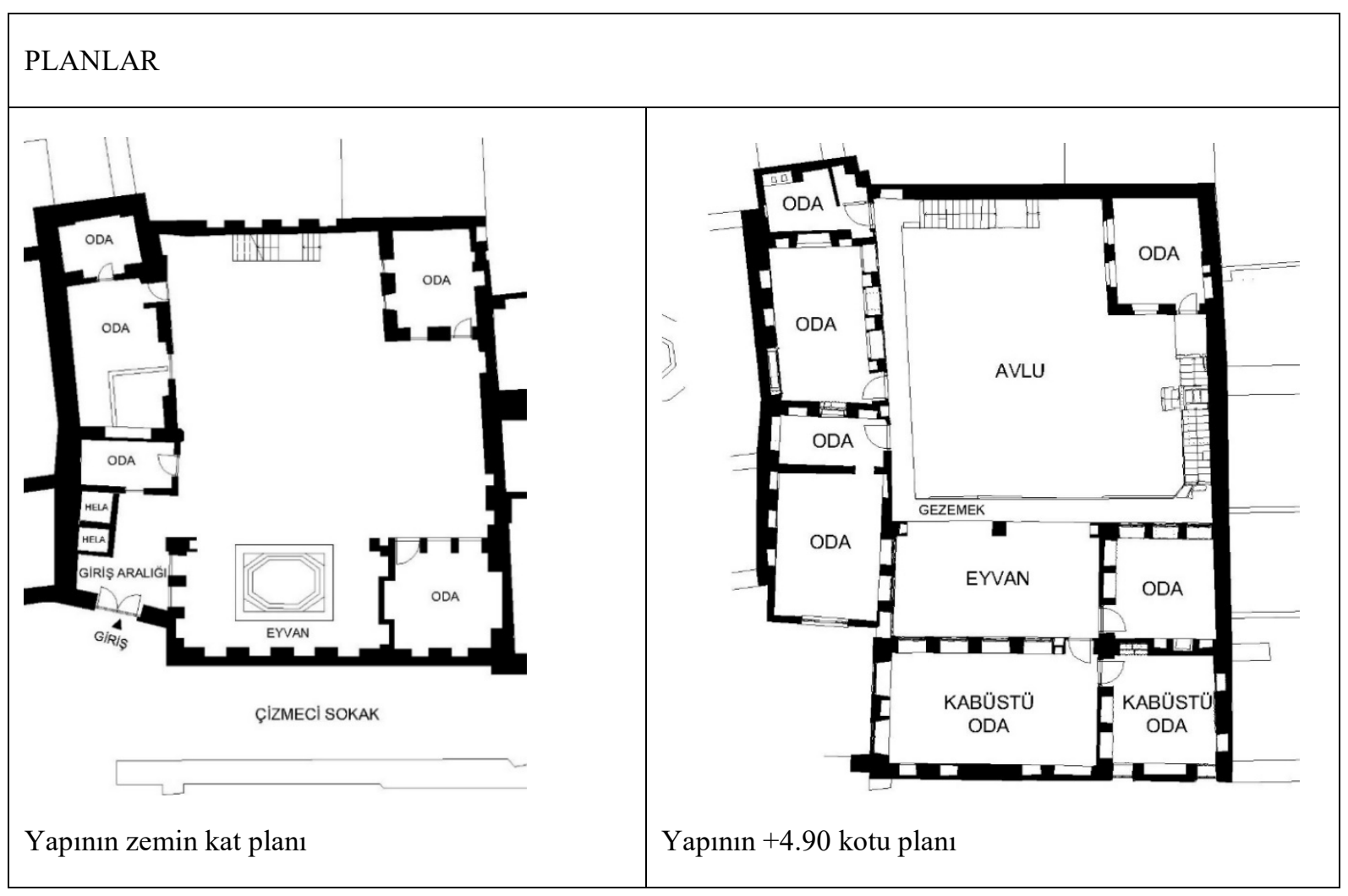

Şekil 9. Mehmet Uzun Evi Planları (Kaya, 2011) 


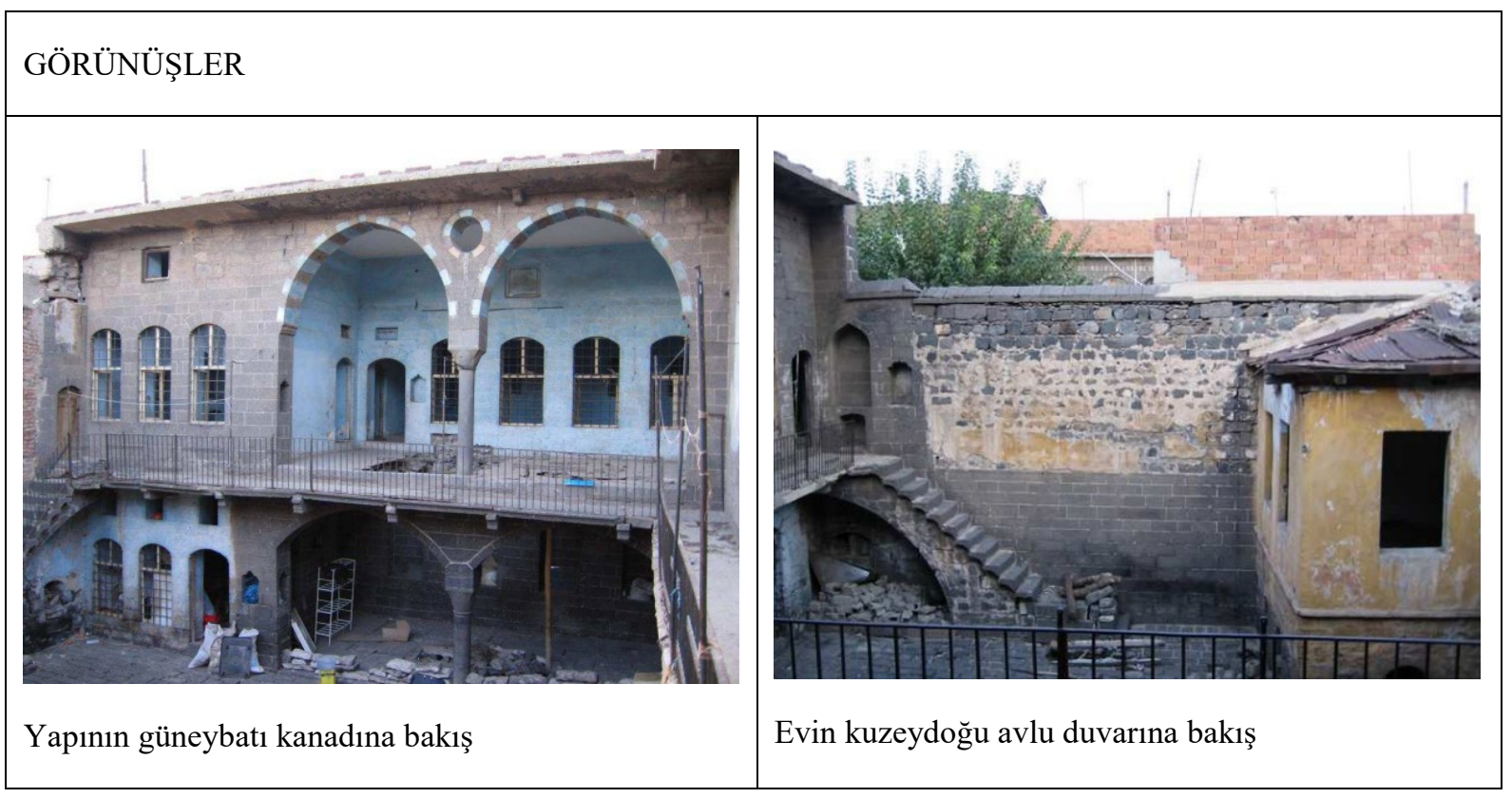

Şekil 10. Mehmet Uzun Evi Görünüşleri (Kaya,2011)

Yapıya güneyden basık kemerli bir kapıdan girilmektedir. Güney kanadı kemerli bir eyvandan ve basık kemerli bir mekandan oluşmaktadır. Yapıda zemin katta ve birinci katta olmak üzere iki eyvan bulunmaktadır. Yapının üst katlarına, avluda bulunan bazalt taşından inşa edilmiş merdivenlerle ulaşılmaktadır. Merdivenler, avluyu evin birinci katındaki gezemeğe bağlamaktadırlar. Yapının kuzeybatı kanadındaki odalara, gezemeğe açılan kapılardan girilirken, diğer yapı kanadında önce gezemekten eyvana buradan da diğer odalara geçilmektedir. Eyvana açılan odalar sokakta kabaltının üstüne denk gelmektedir (Kaya, 2011).

- Diyarbakır geleneksel evlerinde yaşamın sokakla ilişkisi sınırlı tutulmuştur. Konut tasarımında mahremiyet ön plandadir.

- Mehmet Uzun Evi’nde iki kat yüksekliğinde sağır avlu duvarının bulunduğu görülmektedir. Zemin ve birinci katı sokaktan ayıran yüksek avlu duvarları kadının mahrem olarak görüldüğünün örneğidir.

- Diyarbakır geleneksel evlerinde ev halkının özellikle kadınların birçok zamanı avluda geçmektedir ve avlu odalarla ilişkilidir.

• Konut avlu tarafından güçlü bir şekilde gizlendiği için pencere açıklıkları geniş tutulmuştur.

- Zemin katta ve birinci katta olmak üzere iki adet eyvan bulunmaktadır. Misafir geldiği zaman cinsiyet ayrımının eyvanlarda da görülmesi olasıdır.

- Odalar birden fazla ihtiyaca cevap verecek şekilde kullanılmaktadır.

- Genellikle erkek misafirleri ağırlamak için kullanılan misafir odaları günümüzde bile Diyarbakır halkının vazgeçemediği mekandır.

\subsection{Rize-Fındıklı Aydınoğlu Evi}

Yapı, Rize ili Fındıklı ilçesi 127 ada 164 parselde bulunmaktadır (Tablo 5),(Şekil 11-12). 
Tablo 5. Aydınoğlu Evi Künye Bilgileri

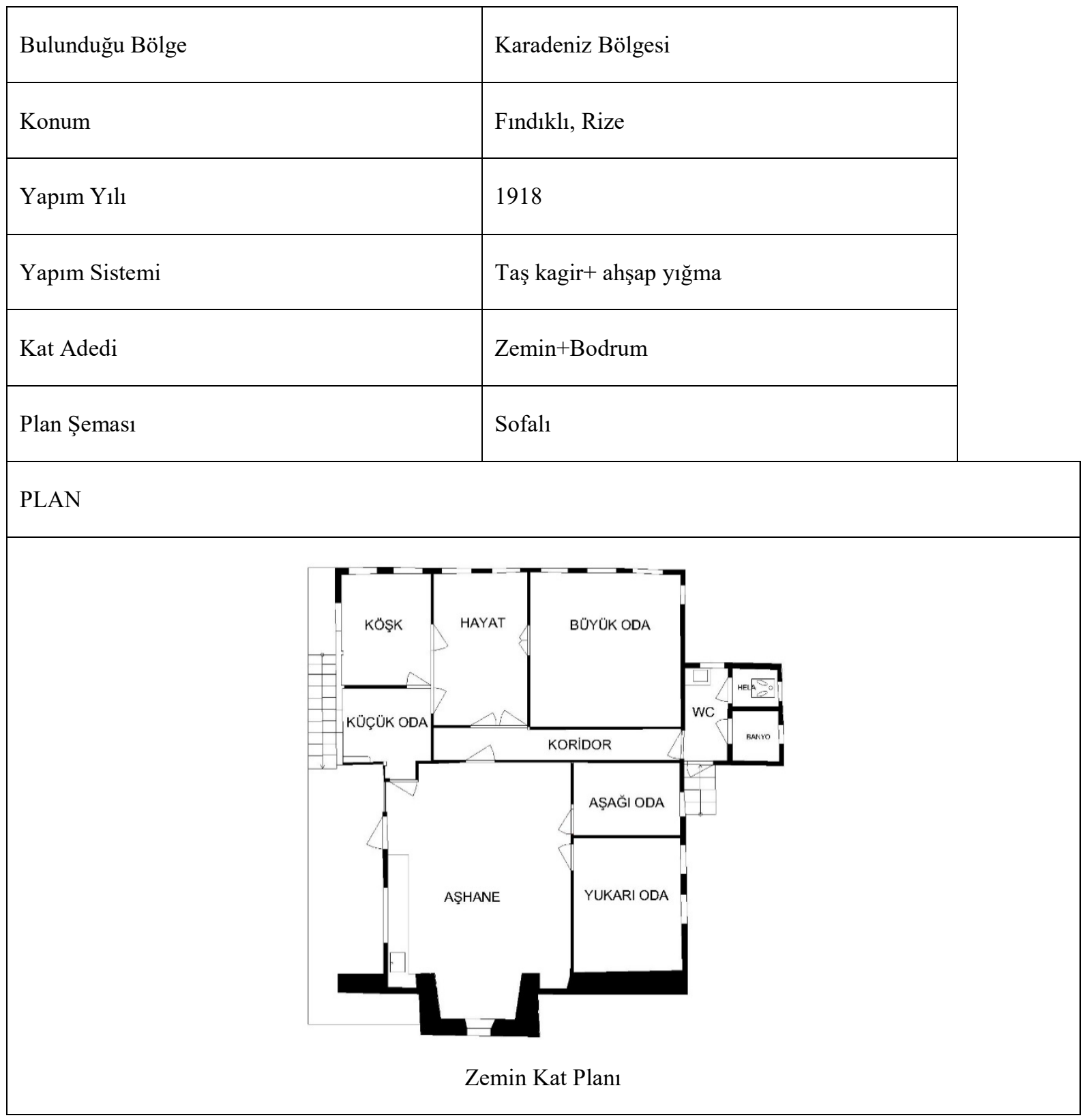

Şekil 11. Aydınoğlu Evi Planı (Güler, 2012) 


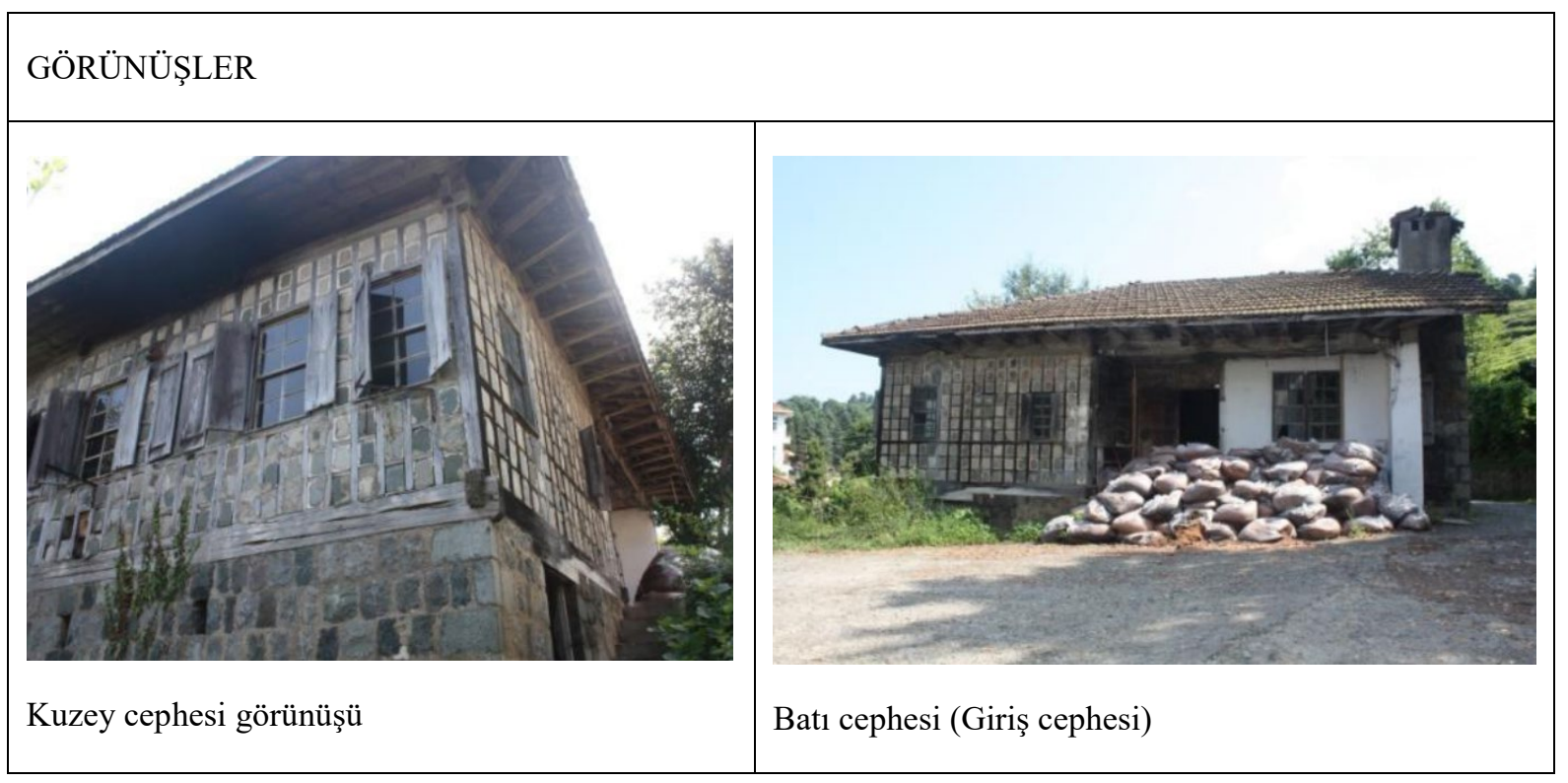

Şekil 12. Aydınoğlu Evi Görünüşleri (Güler, 2012)

Yapının doğu ve batı cephesinde olmak üzere iki ayrı girişi bulunmaktadır. Batı cephesinde bir avluyla ulaşılan ve yapının yaşama mekanına ulaşılan ana giriş mevcuttur. Bodrum kattan günümüzde betonarmeye çevrilen merdivenlerle avluya ulaşılmaktadır. Zeminden birkaç basamakla yükseltilen ve islak mekanlara dişarıdan ulaşım sağlayan doğu cephesindeki giriş ikincil konumdadır (Güler, 2012).

Avludan girişte günlük hayatın geçtiği ve şu anda kapatılmış olan ocaklık bölümünün yer aldığı salon bölümüne geçilmektedir. Salona üç odanın kapılarıyla birlikte ıslak hacimler ve hayatla ilişkiyi kuran koridor açılır. Hayat, denize paralel konumlanmıştır ve diğer üç odayla ilişkiyi kurmaktadır. Serender, tahıl saklanması ve yiyeceklerin kurutulması için yapılan mekan, yapının doğu cephesinde ve 4 ahşap dikme üstünde yükselmiştir. Bodrum katında bir su kuyusu bulunmaktadır. Üst kota ulaşılan merdivenin zaman içerisinde kaybolduğu görülmektedir (Güler, 2012).

• Karadeniz bölgesi konut plan şemasını etkileyen en önemli unsur yaşam biçimidir.

- Yapım sisteminden dolayı büyük pencereler açılamamıştır. Buna rağmen giriş cephesinde diğer cephelerine kıyasla daha az pencere yapıldığı görülmektedir.

- İklimi uygun olmadığı için avlu kavramına burada rastlanmaz. Sofalı plan tipine sahiptir.

• Ev halkının büyük zamanını geçirdiği sofa mekanı evin en korunmuş bölgesinde yer alır.

- Konutta büyük oda, başoda olarak kullanılmaktadır. Bu oda misafire verilen değerin ve mahremiyetin göstergesi niteliğindedir.

- Odalarda ocak bulunmaktadır ve bu sayede odalar gerekli ihtiyaçlara cevap verebilecek konumdadır. Ev halkının ortak kullanımına açık mekanlardır.

- Karadeniz'de genellikle kadınlar da kocalarıyla beraber tarlalarda çalışır, beraber işe gidip gelirler. Eve döndüklerinde ev sorumluluğu yine kadınlara aittir.

- Plan şemasında koridor ve sofanın bulunması ve her kapının işlevine göre ayrı yere açılması kullanıcıları ayırmış aynı zamanda mahremiyete önem verdikleri göstermektedir. 


\subsection{Bursa-Kenan Doğruöz Konağı}

Yap1, Musabey Mahallesi, 1056 ada, 33 parselde bulunmaktadır (Tablo 6),(Şekil 13-14).

Tablo 6. Kenan Doğruöz Konağı Künye Bilgileri

\begin{tabular}{|l|l|}
\hline Bulunduğu Bölge & Marmara Bölgesi \\
\hline Konum & Mudanya, Bursa \\
\hline Yapım Yılı & 17. yy \\
\hline Yapım Sistemi & Ahşap Karkas+Taş Kagir \\
\hline Kat Adedi & Bodrum+Zemin+1 \\
\hline Plan Şeması & Dış Sofalı \\
\hline
\end{tabular}

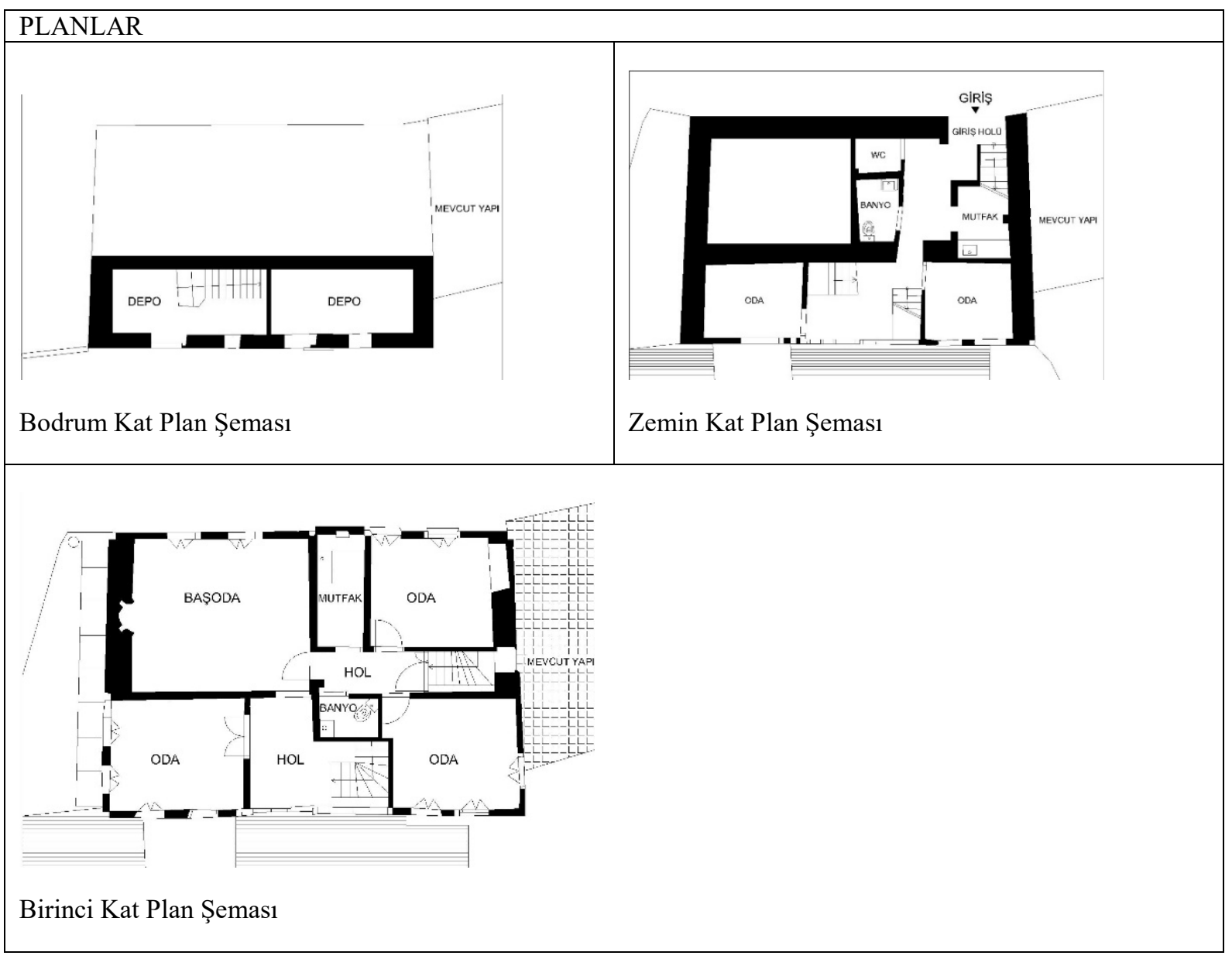

Şekil 13. Kenan Doğruöz Konağı Planları (Evran, 2018) 


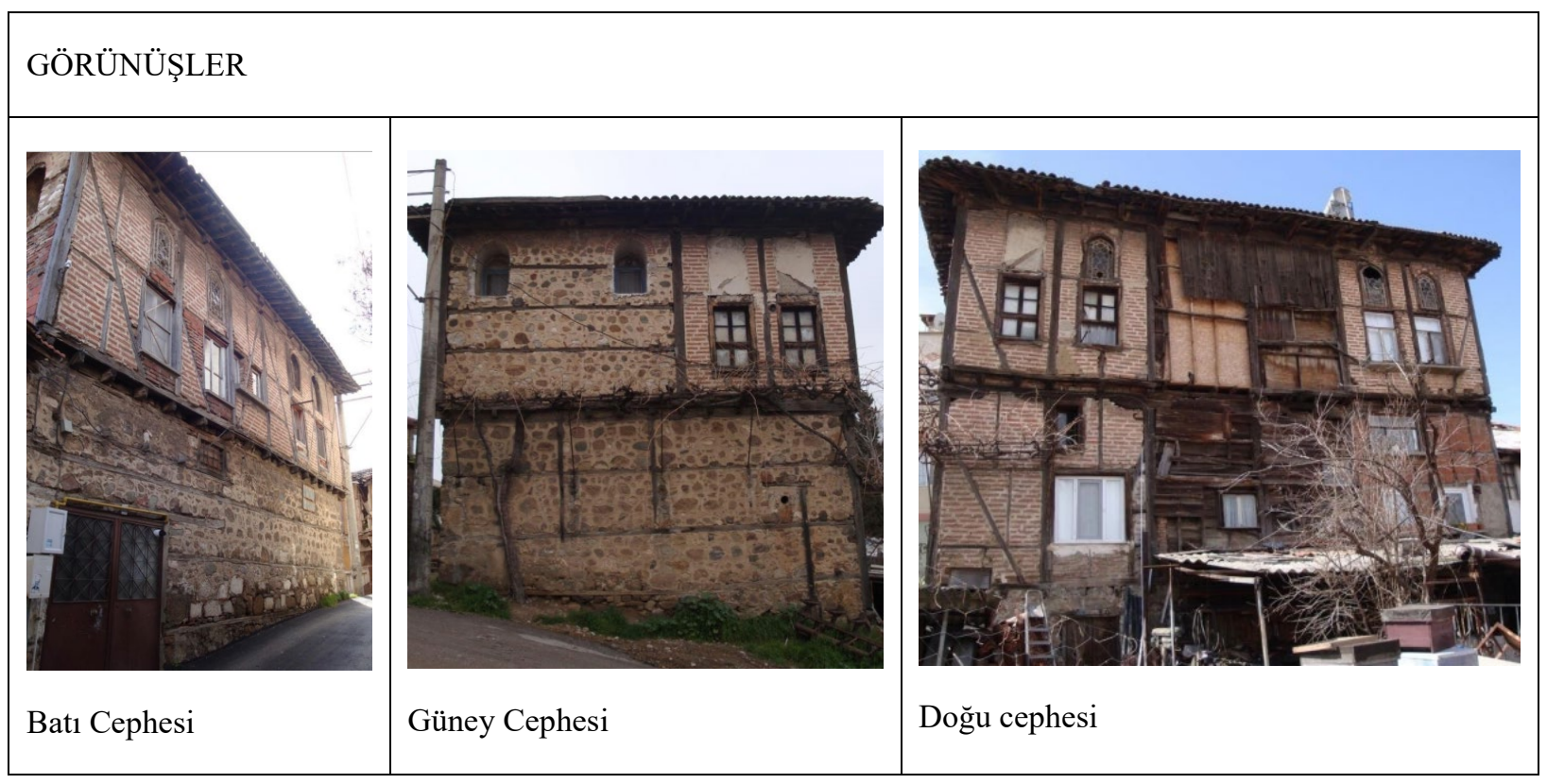

Şekil 14. Kenan Doğruöz Konağı Görünüşleri (Evran, 2018)

Yapının plan şeması bodrum, zemin ve birinci kat olmak üzere üç katlıdır. Yapıya giriş batı cephe zemin katta bulunan demir kapıdan ve doğu cephe bodrum katta bulunan ahşap kapıdan yapılmaktadır. Birinci katta odaların sokağı ve sofayı gören pencerelerinin üzerinde tepe pencereleri tasarlanmıştır. Pencere sayısı diğer katlara göre fazla olan birinci katta köşelerde, büyük olan başoda olmak üzere, dört adet oda bulunmaktadır. Servis mekanları birbirleriyle ilişkilidir, birinci katta yer alan mutfaktan kışlık katta yer alan depo ve mutfağa merdivenle erişim sağlanmaktadır (Evran, 2018).

- Yapının bodrum ve zemin katındaki konuta giriş kapıları haricinde pencere boşluğu açılmamış ve sokakla ilişkisi net bir şekilde kesilmiştir.

- Birinci katta odalara açılan pencerelerde herhangi bir sınırlamaya gidilmemiş ancak kadının sürekli bulunduğu mutfak mekanında küçük boyutlarda pencere açılmıştır.

- Bahçeye bakan doğu cephesinde zemin katta pencereler açılmış yani bahçeyle bütünleşik bir yapı olduğu görülmektedir.

- Geleneksel Türk evlerinde olduğu gibi bahçe önemli bir yere sahiptir ve mahremiyetin sağlandığı bölümdür.

- Konuta giriş mahremiyetin ön planda olduğu ve genellikle kadınların kullandığı alan olan bahçeden tek kanatlı ahşap bir yapıyla sağlanırken sokak cephesinden ise çift kanatlı yarı saydam bölmeleri olan demir bir kapıyla sağlanmaktadır. Genellikle kadınların kullandığı kapı açıklıksız, tek kanatı iken evin erkeğinin işten gelip girdiği kapı dışarıdan iç taraf hakkında ipucu veren açıklıklı ve çift kanatlıdır (Evran, 2018) .

• Bahçenin iki cephesi tuğla duvarlarla çevrilidir ve insan göz hizasını aşan bir yüksekliğe sahiptir.

- Birinci katta bulunan erkeklerin misafir ağırladığı oda olan başoda geleneksel Türk evlerinde görüldüğü gibi diğer odalara göre daha büyüktür ve tepe pencereleri bulunan tek odadır.

• Genel olarak bakıldığında dışa kapalı içe dönük, mahremiyetin ve cinsiyet ayrımcılığın görüldüğü bir yapıdır. 


\subsection{Erzincan-M. Tamer Aksoy Evi}

Yapı, Başpınar Köyü, Yukarı Mahallesi, 262 ada, 3 nolu parselde bulunmaktadır (Tablo 7),(Şekil 15-16).

Tablo 7. M. Tamer Aksoy Evi Künye Bilgileri

\begin{tabular}{|l|l|}
\hline Bulunduğu Bölge & Doğu Anadolu Bölgesi \\
\hline Konum & Kemaliye, Erzincan \\
\hline Yapım Yılı & 19. yy’ın ilk yarısı \\
\hline Yapım Sistemi & Taş Kagir \\
\hline Kat Adedi & Zemin +3 \\
\hline Plan Şeması & İç Sofalı \\
\hline
\end{tabular}

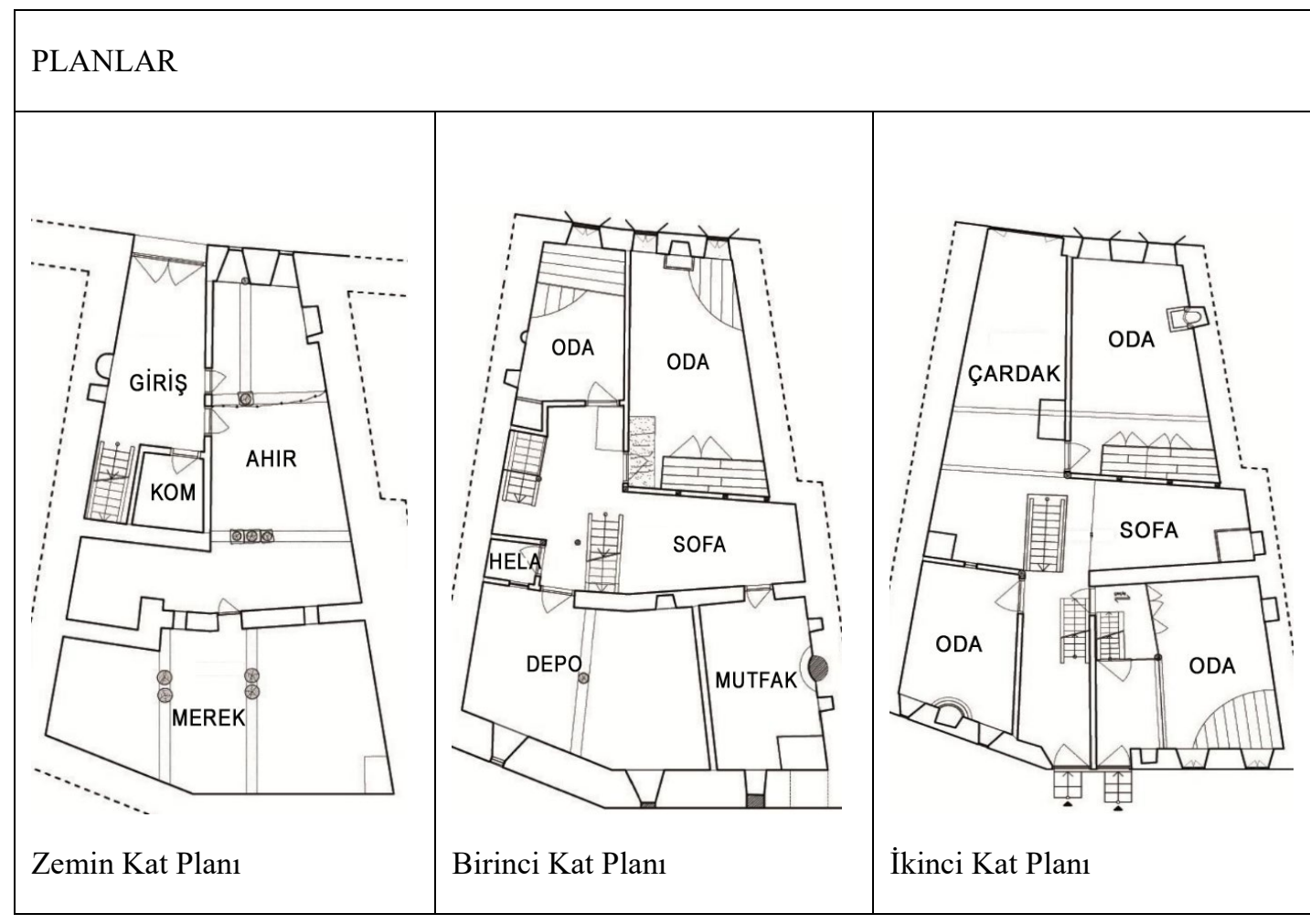

Şekil 15. M. Tamer Aksoy Evi Planları (Efeoğlu, 2014) 


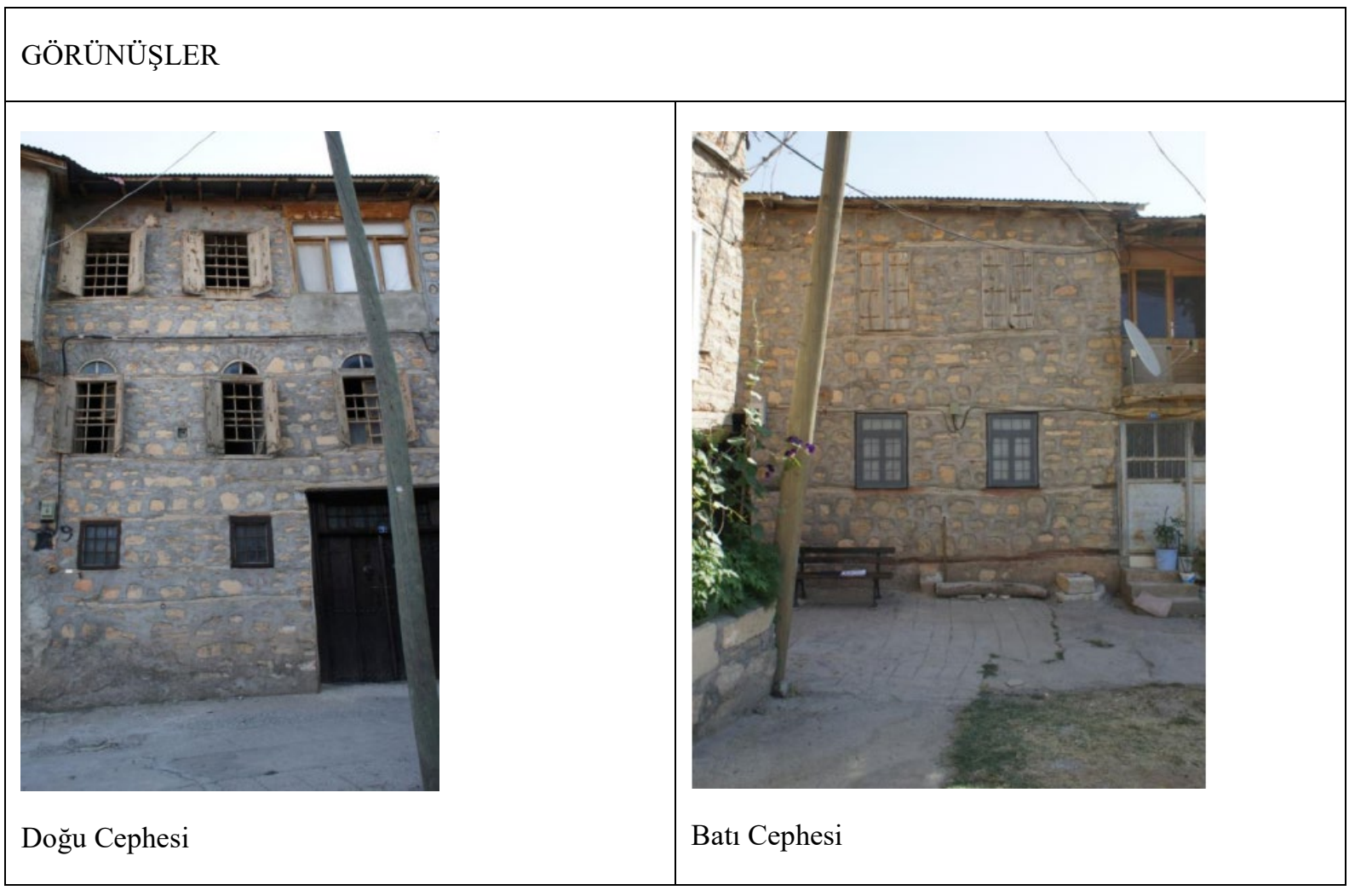

Şekil 16. M. Tamer Aksoy Evi Künye Bilgileri (Efeoğlu, 2014)

M. Tamer Aksoy Evi, dört katlı kargir bir yapıdır. Bitişik nizamda inşa edildiğinden yapının kuzey ve güney cephelerinde birer konut mevcuttur. Eğimli bir araziye oturan bina, doğu cephesinden bakıldı̆̆ında üç katlı, köy meydanından yani batı cephesinden bakıldığında ise iki katlıdır. Yapının doğu cephesi ile batı cephesi arasında $4.50 \mathrm{~m}$ kot farkı bulunmaktadır. Yapıya, batı cephesinde bulunan biri özgün tek kanatlı ahşap kapı ve diğeri sonradan yapılmış demir bir kapıdan, doğu cephesinden ise özgün çift kanatlı ahşap bir kapıdan girilmektedir (Efeoğlu, 2014).

Yapının zemin katında hayvancılıkla ilgili olarak merek, kom ve ahır mekanları mevcuttur. Zemin katında mutfak, depo gibi servis alanları ve iki oda bulunmaktadır. İkinci katta ise otların kurutulduğu çardak, farklı büyüklüklerde üç oda ve sofa yer almaktadır.

- Yapının sokağa bakan tarafi yani doğu cephesinde zemin katta yüksek kotta bulunan diğer katlara göre genişliği az olan iki pencere bulunurken birinci ve ikinci katlarda üç adet daha geniş pencereleri bulunmaktadır.

- Köy meydanına bakan yani batı cephesinde, doğu cephesinde olduğu gibi sokak kotundan yüksekte yer alan sayıca az pencereler ve üst katlarda daha geniş ferah pencereler bulunmaktadır.

- Yapıya giriş meydan tarafından tek kanatı ahşap bir kapı ile sağlanırken doğu cephesinde çift kanatlı ahşap kapıyla sağlanmaktadır.

- Kap1 ve pencerelerde görüldüğü gibi meydan cephesinde mümkün olduğu kadar mahremiyet korunmaya çalışılmıştır.

- Birinci ve ikinci katlarda diğer odalara oranla daha büyük, erkeklerin misafirleri ağırladığı odalar bulunmaktadır.

- Evin iç dengesini sağlayan kadının gününün çoğunu geçirdiği mutfak mekanında sonradan kapatılan bir adet pencere bulunmaktadır ve kış aylarında yiyecek ihtiyacının karşılandığı depoyla ilişkilidir.

- Başodalar, mutfak, depo ve servis mekanları haricindeki odalar ailenin ortak kullandığı mekanlardır. 
- Doğu Anadolu Bölgesi’nde bulunan M. Tamer Aksoy Evi’nde mahremiyet ve kadın etkileri açık bir şekilde görülebilmektedir.

\section{SONUÇ:}

Çalışmada mimarlık tarihinde kadının konut mimarisindeki etkisi irdelenmiştir. Daha sonra Türkiye ile sınırlandırılarak ülkemizde geçmişten günümüze kadın ve mimarlık ilişkisi çevresel, dinsel, sosyokültürel boyutunda ele alınmıştır. Yaşamın her anında mahrem olarak görülen kadının, konutu etkilediği bir gerçektir. Buna bağlı olarak konut, yöresel konutlarla sınırlandırılarak Türkiye'de farklı iklim verilerine sahip bölgelerden örnek konutlar seçilerek plan ve cepheleri incelenmiş, kadın için mekanın nasıl şekillendiği değerlendirilmiştir. Bu bağlamda aşağıdaki tabloda bölgelere göre oluşmuş olan mekânsal ayrım verişmiştir (Tablo 8).

Tablo 8 Bölgelere Göre Kullanıcı Gruplarinin Etkili Oldukları Mimari Mekanlar

\begin{tabular}{|c|c|c|c|}
\hline \multicolumn{4}{|c|}{$\begin{array}{l}\text { BÖLGELERE GÖRE KULLANICI GRUPLARININ ETKILI OLDUKLARI MIMARI } \\
\text { MEKANLAR }\end{array}$} \\
\hline \multirow{3}{*}{$\begin{array}{l}\text { İç Anadolu Bölgesi - Eskişehir } \\
\text { Odunpazarı Hasan Şefik Evi }\end{array}$} & KADINLAR & ERKEKLER & ORTAK KULLANIM \\
\hline & Mutfak & \multirow{2}{*}{ Başoda } & Odalar \\
\hline & Bahçe & & Banyo/Wc \\
\hline \multirow{3}{*}{ Ege Bölgesi - Denizli Enver Soylu Evi } & Mutfak & \multirow{3}{*}{ Başoda } & Odalar \\
\hline & \multirow{2}{*}{ Bahçe } & & Sofa \\
\hline & & & Wc \\
\hline \multirow{3}{*}{$\begin{array}{l}\text { Akdeniz Bölgesi - Antakya Çinçin } \\
\text { Ailesi Evi }\end{array}$} & Mutfak & \multirow{3}{*}{ Misafir Odas1 } & Odalar \\
\hline & Avlu & & Yemek Odası \\
\hline & Livan (Seki) & & Banyo/Wc \\
\hline \multirow{3}{*}{$\begin{array}{l}\text { Güneydoğu Anadolu Bölgesi - } \\
\text { Diyarbakır Mehmet Uzun Evi }\end{array}$} & Avlu & \multirow{3}{*}{ Misafir Odas1 } & Odalar \\
\hline & Eyvan & & \\
\hline & Mutfak & & Banyo/Wc \\
\hline \multirow{3}{*}{$\begin{array}{l}\text { Karadeniz Bölgesi - Rize Fındıklı } \\
\text { Aydınoğlu Evi }\end{array}$} & Aşhane & \multirow{3}{*}{ Başoda } & Odalar \\
\hline & Serender & & Hayat \\
\hline & Bahçe & & Banyo/Wc \\
\hline \multirow{3}{*}{$\begin{array}{l}\text { Marmara Bölgesi - Bursa Kenan } \\
\text { Doğruöz Konağ } 1\end{array}$} & Mutfak & \multirow{3}{*}{ Başoda } & Odalar \\
\hline & Bahçe & & Banyo/Wc \\
\hline & Depo & & Sofa \\
\hline \multirow{3}{*}{$\begin{array}{l}\text { Doğu Anadolu Bölgesi - Erzincan M. } \\
\text { Tamer Aksoy Evi }\end{array}$} & Mutfak & \multirow{3}{*}{ Başoda } & Odalar \\
\hline & Depo & & Banyo/Wc \\
\hline & Çardak & & Sofa \\
\hline
\end{tabular}

Çalışmada çıkarılan sonuçlar ise aşağıdaki gibidir:

Toplumsal yapının etkisiyle konutla bütünleşen kadın, tarihte dönem dönem konut üzerindeki rollerinin değiştiği görülmektedir. İslamiyet öncesi Türk toplumlarında çadır dışında kadın-erkek ayrımı olmadığı görülmektedir. Yuvarlak çadırının bir tarafı kadına, mutfağa ayrılırken diğer tarafı erkeğe misafir ağırladığı yere ayrılmaktadır. Başoda kavramının çıkışı İslamiyet öncesinde görülmektedir. 
İslamiyet sonrası toplumlarda kadın kısıtlanmış ve kadının mekanının konut olduğuna karar verilmiştir. Bunların sonucu olarak konut kadına göre şekillenmiştir. Evin bir kısmının mutfak, depo, oda kullanımının kadınlara ayrıldığı, bir kısmının evin reisi erkeğe ayrıldığı görülmektedir. Başodalarda erkek misafir ağırlarken, kadınlar mutfakta ev işlerini yapmışlardır. Bu anlayış geleneksel konutlarda da kendini göstermiştir. Yüksek kotta yer alan pencereler, ahşap kepenkler, yüksek bahçe duvarları, başodalar (daha sonra misafir odasına evrilmektedir) gibi mimari ögelerle geleneksel konutlarda kadınlara ait mekanlar tasarlanmıştır.

Çalışmada incelenen geleneksel konutlara ve ait oldukları bölgenin mimarisine bakıldığı zaman aşağıdaki gibi bölgelere dair cinsiyet ayrımı ve mahremiyet sonuçlarına varılmıştır:

$>$ İç Anadolu Bölgesi geleneksel konutları genellikle iç sofalı ve çok katlı yapılardır. Zemin katında mutfak, depo gibi servis mekanları bulunur bu da evin hanımının zemin katta işlerini kolayca yapabilmesini sağlar. Zemin katlarda pencerelerin küçük ve aynı zamanda yüksek kotlarda yer alması içe dönüklüğü yani mahremiyeti temsil eder. Üst katlarda pencereler hem daha çok hem de daha geniştir. Servis mekanları sadece kadınlara; evin üst katlarında, köşelerde yer alan diğer odalara göre daha büyük olan başoda erkeklere, geri kalan tüm odalar ise ortak kullanıma hizmet etmektedir. İç Anadolu Bölgesi geleneksel konutlarında mahremiyet ve cinsiyet ayrımının mimari mekana yansımalara açık bir şekilde görülmektedir.

$>$ Ege Bölgesi geleneksel konutları genellikle ikliminden dolayı bahçeli, tek veya iki katlı yapılardan oluşmaktadır. Bahçe ev halkının sık kullandığı mekândır. Mahremiyeti yüksek duvarlar ve büyük ağaçlar sağlamaktadır. Zemin katta tuvalet, mutfak gibi ortak kullanım alanları bulunur. Zemin katlarda pencereler diğer bölgelerdeki geleneksel konutlara göre sayıca daha çoktur ve diğer katlardaki pencerelerle uyumludur. Odalar herkesin kullanımına uygun olacak şekilde yapılmıştır. Başoda bu bölgede yaygın olarak kullanılmamaktadır.

Akdeniz Bölgesi geleneksel konutları genellikle topografyaya uyumlu, iklime bağlı olarak sofalı, avlulu veya bahçeli, bir veya iki katlı yapılardan oluşmaktadır. Birden fazla katı olan konutlarda zemin kat hayvancılık, tarım ürünleri için kullanılmaktadır. Tek katlı yapılarda ise servis mekanları bir tarafta, başoda ve odalar diğer tarafta yer almaktadır. Geleneksel Türk evlerinde erkeklerin misafirlerini ağırladıkları mekan olan başoda bu bölgede de kendini göstermektedir. Servis mekanlarında kadınlar işlerini yaparken, evin bir tarafını erkekler kullanmaktadır. Cephelerde zemin katta ve avluda mahremiyet ön planda tutularak az pencereli, sağır duvarlı içe dönük yapılar görülmektedir. Odalar birçok işleve cevap verebilir niteliktedir ve ev halkının toplandığı alanlardır. Avlu, bahçe ve servis mekanları kadınlara yönelik, başodalar ise erkeklere yönelik mekanlar olmuştur. Akdeniz Bölgesi geleneksel konutlarında kadının mahrem olarak görüldüğü ve mimari mekanların mahremiyet düşüncesiyle şekillendiği görülmektedir.

> Güneydoğu Anadolu Bölgesi geleneksel konutları genellikle bitişik nizamlı, iklimden dolayı avlulu ve geleneksel malzemelerle inşa edilen yapılardır. Konutlar girişten başka sokakla ilişkisi olmayacak şekilde avlu ve bahçe sağır duvarlarıyla gizlenmiştir. Avlu kadının en çok vakit geçirdiği yerdir bu sebeple avlu mahremiyetine çok önem verilmiştir. Bölgenin geleneksel konutlarında harem-selamlık ayrımı açık bir şekilde görülmektedir. Evde selamlık bölümünde misafir olduğu zaman harem ve selamlık arasında bulunan ve kendi etrafında dönen bir dolap aracılığıyla misafirlere ikramlık servisi yapılabilmektedir. Bazı konutlarda ayrı giriş ve ayrı avluya kadar da kadın cinsiyetine yönelik mahremiyet arttırılmaya çalışılmıştır. Zemin katın sokağa cephesi var ise pencereler sınırlı tutulmuştur ve bölgenin konut mimarisi içe dönük yapılardan oluşmaktadır. Odalar kadın ve erkeğin kullanımına uyumlu olacak şekilde yapılmıştır. Başoda yani misafır odası erkeklerin misafirlerini ağırladıkları geniş odadır. Geleneksel olmayan Güneydoğu Anadolu Bölgesi konutlarında misafir odası(başoda) hala önemli bir yer tutmaktadır. Sonuç olarak Güneydoğu Anadolu Bölgesi geleneksel konutlarında kadın ve erkeğin, ev içinde sorumluluklarının ve etkili oldukları mekanların ayrıldığı görülmektedir.

$>$ Karadeniz Bölgesi geleneksel konutları genellikle sofalı, bir veya iki katlı ve bahçeli yapılardır. zemin katta veya bodrum katta kadınların evdeki zamanlarının çoğunu geçirdikleri mutfak, kiler, ambar gibi servis mekanları bulunmaktadır. Karadeniz Bölgesi'nde yapılan çay, fındık toplama gibi tarla işlerinde genellikle kadınlar da erkeklerle beraber çalışmakta fakat evde ev işleri yine kadının sorumluluğuna bırakılmaktadır. Konutlarda kadınların daha çok bulunduğu zemin katta pencere sayıları az ve pencereler yüksek kotta yapılmıştır. Üst katlarda pencere sayıları arttırılmış ve genişletilmiştir. Geleneksel Türk evinde görülen başoda kavramına bu bölgede de rastlanmaktadır. Başoda hem misafirliğe hem de mahremiyete verilen 
önemin göstergesidir. Karadeniz Bölgesi geleneksel konutlarında plan ve cephe düzeninden mahremiyete verilen önem açık bir şekilde görülmektedir.

> Marmara Bölgesi geleneksel konutları genellikle iki veya üç katlı, sofalı ve bahçeli yapılardır. Konut girişleri sokaktan ve bahçeden dolaylı olarak farklılık göstermektedir. Mutfak, kiler gibi küçük pencereli birimler zemin kat bahçeyle bütünleşmektedir. Konutun birinci katında pencere sayıları ve genişlikleri artmaktadır. Birinci katlar genellikle cumbalıdır böylece konut sokağa ve bahçeye yönelerek dışa dönük bir mimari mekan haline gelmektedir. Sofa aile bireylerinin beraber vakit geçirdiği ve en çok kullanılan mekandır. Başoda erkeklerin misafir ağırladıkları alandır ve diğer odalardan daha büyüktür. Daha çok kadınların kullandığ́ servis mekanlarıyla bütünleşen bahçe yüksek duvarlarla ve meyve ağaçlarıyla mahremiyeti sağlamaktadır. Marmara Bölgesi geleneksel konutlarında cephe ve plan özelliklerinde mahremiyet ve buna bağlı olarak mekanların cinsiyeti olduğu açık bir şekilde görülmektedir.

D Doğu Anadolu Bölgesi geleneksel konutları genellikle sofalı, iki veya üç katlı yapılardır. Konut yapısı Anadolu evleriyle benzerlik göstermektedir. Yapıların zemin katında pencere sayısı diğer katlara göre sayıca az tutulmuş, kat giriş kotundan daha yüksek kotta tasarlanmış ve bu katta küçük pencereler kullanılmıştır. Üst katlarda pencere sayıları ve büyüklükleri artmaktır. Konut girişleri topografyaya göre değişiklik göstermektedir bazı evlere giriş iki ayrı kotta yapılabilmektedir. Böyle durumlarda sokak ya da meydan gibi insan sirkülasyonunun fazla olduğu yöne bakan girişler erkeklerin kullanımına daha uygun görülmüştür. Servis mekanları kadının kullanımını kolaylaştıracak biçimde birbirleriyle ilişkilidir. Odalar ailenin hepsinin kullanımına uygun olacak şekilde yapılmıştır. Başodalar Anadolu konutlarında görüldüğü gibi erkeklerin misafir ağırladıkları alandır. Doğu Anadolu Bölgesi geleneksel konutlarında cinsiyet ayrımcılığının konutu şekillendirdiği görülmektedir.

\section{GENEL SONUÇ}

Bölge incelemelerinden görüldüğü gibi iklim, toplumsal yaşam, topografya gibi değişkenlere bağlı olarak konut yapıları değişiklik göstermektedir. Türkiye'de geleneksel konutlar birbirleri arasında benzerlik gösterseler de hepsi kendi başına değerleri ve gelenekleriyle Türk evini yansıtmaktadır. Sofalı, avlulu, bahçeli plan tipleriyle; pencere sayıları, genişlikleriyle ve kapı girişleriyle bile konut tasarımında mahremiyetin temel alındığı görülmektedir. Odalar ortak kullanıma uygun olsa da geleneksel Türk evlerinin hemen hepsinde erkeklerin misafirlerini ağırladığı, sadece erkeklere ait ve diğer odalara göre daha büyük olan, başodaya rastlanmaktadır. Kadınların mahrem görüldüğü ve ev içinde cinsiyet ayrımı sonucu odaların farklı cinsiyetlere hizmet ettiği sonucuna varılmaktadır.

Yedi bölgede incelenen yedi geleneksel konutla kadının konuta etkisi mimari ögelerle açıklanmaya çalışılmıştır. Bölgeler özelinde çıkarılan sonuçlardan da görülmektedir ki kadının konutla etkileşimi gözardı edilemez. Kadının konut ile etkileşiminde belirli parametreler vardır ve geçmişten günümüze konut her zaman bu belirleyicilere göre tasarlanmıştır.

\section{Etik Standart ile Uyumluluk}

Çıkar Çatışması: Yazarlar herhangi bir çıkar çatışmasının olmadığını beyan eder.

Etik Kurul İzni: Bu çalışma için etik kurul iznine gerek yoktur

Finansal Destek: Yoktur. 


\section{KAYNAKÇA:}

Arel, Ayda (1982). Osmanlı Konut Geleneğinde Tarihsel Sorunlar. İzmir: E.Ü. Güzel Sanatlar Fakültesi (47-80)

Cıbıroğlu, Y. (2004). Kadın ve Yapı İlişkisi. Mimarist, (14), 67-72.

Dostoğlu Türkün, N., Eraydın, A., Türkün, A., Kayasü, S., Özgüven, Y., Erkarslan Erdoğdu, Ö. ve diğer. (2005).

Cumhuriyet Dönemi Mimarlı̆̆ı ve Şehirciliği-I: Cumhuriyet Döneminde Kadın ve Mimarlık (1. Baskı). Ankara: TMMOB Mimarlar Odas1.

Ediz, Z. (1995). Kadınların Tarihine Giriş; Hititlerden Günümüze. İstanbul: Adım Yayıncılık.

Efeoğlu, M. (2014). Kemaliye, Başpınar'da Geleneksel Konutların Yapım Tekniklerinin Incelenmesi ve M. Tamer Aksoy Evi Restorasyon Önerisi. Yüksek Lisans Tezi. İstanbul: Y1ldız Teknik Üniversitesi.

Evran, A. (2018). Mudanya Kenan Doğruöz Konă̆g Restorasyon Projesi. Yüksek Lisans Tezi. Bursa: Uludağ Üniversitesi.

Güler, K. (2012). Doğu Karadeniz Kırsal Mimarisi Örneklerinden Rize-Fındıklı Aydınoğlu Evi Restorasyon Projesi. Yüksek Lisans Tezi. İstanbul: İstanbul Teknik Üniversitesi.

İnan, A. (1964). Atatürk ve Türk Kadın Haklarının Kazanılması: Tarih Boyunca Türk Kadınının Hak ve Görevleri (2. Baskı). İstanbul: Milli Eğitim Bakanlığı Basımevi.

Kaya, Ş. (2011). Diyarbakır Mehmet Uzun Evi Restorasyon Projesi. Yüksek Lisans Tezi. İstanbul: İstanbul Teknik Üniversitesi.

Kuban, D. (2007). Osmanlı Mimarisi (1. Bask1). İstanbul: YEM Yayın.

Küçükerman, Ö. (1985) Kendi Mekanının Arayışı Içinde Türk Evi. İstanbul: Türkiye Turing ve Otomobil Kurumu Yayını.

Mumford, L. (2007). Tarih Boyunca Kent Kökenleri, Geçirdiği Dönüşümler ve Geleceği (1. Bask1). Gürol Koca ve Tamer Tosun (Çev). İstanbul: Ayrıntı Yayınları.

Nesbit, M. (1992). “In the absence of the Parisienne... ”. B. Colomina (Ed.). Sexuality \& Space. Princeton (307325). New Jersey: Princeton University School of Architecture.

Nurlu, S. (2020). Koruma Yöntemlerinden Biri Olan Yeniden İşlevlendirme Kavramının Çevresel Etkileri Antakya Konak Restoran Örneği. Yüksek Lisans Tezi. İstanbul: Beykent Üniversitesi.

Özbek, M. (2001).Dünden Bugüne İnsan (2. Bask1). İstanbul: İmge Kitabevi.

Özderya, T. (2020). Denizli İli, Pamukkale İlçesi, 15 Mayıs Mahallesi'ndeki Enver Soylu Evi Restorasyon ve Yeniden İşlevlendirme Projesi. Yüksek Lisans Tezi. İstanbul: Fatih Sultan Mehmet Vakıf Üniversitesi.

Özer, Z. (2006). Eskişehir Odunpazarı Hasan Şefik Evi Restorasyon Önerisi. Yüksek Lisans Tezi. Ankara: Gazi Üniversitesi.

Sarıçelik, M. (2017). Mimarlık Kültürünün Oluşumunda Kadının Rolü ve Erken Cumhuriyet Döneminde Mimarlık-Kadın İlişkisi. Yüksek Lisans Tezi. İzmir: Dokuz Eylül Üniversitesi.

Turani, A. (2000). Dünya Sanat Tarihi. İstanbul: Remzi Kitabevi.

Tuztaşı, U. ve Aşkun, İ. Y. (2013). "Türk Evi" İdealleştirmesinde "Osmanlı Evi" ve "Anadolu Evi" Kavramlarının Ortaklıklarına Iliskin İşlevsel Açıklamalar” Bilig YAZ 2013 / Sayı 66, 273-296 
URL 1:

https://www.google.com/url?sa=i\&url=https\%3A\%2F\%2Fwww.otelkutahya.com\%2Fkent-tarihi-muzesi.html\&psig (erişim:01.06.2021)

URL 2:

https://www.google.com/url?sa=i\&url=https\%3A\%2F\%2Fwww.kulturportali.gov.tr\%2Fmedya\%2Ffotograf\%2Ffotodo kuman\%2F6308\%2Fselamlik\&psig=AOvVaw3vBqb2Xz4gG8XGheu4JxYx\&ust (erişim:01.06.2021) 